\title{
FEDERAL RULES, LOCAL RULES, AND STATE RULES: UNIFORMITY, DIVERGENCE, AND EMERGING PROCEDURAL PATTERNS
}

\author{
STEPHEN N. SUBRIN $\dagger$
}

\section{INTRODUCTION}

The most prescient critic of uniform federal rules was not Thomas Walsh, the Montana Senator whose dogged opposition almost singlehandedly prevented passage of the Act that enabled the Federal Rules of Civil Procedure. ${ }^{1}$ That honor belongs to Connor Hall, the West Virginia lawyer who eight years before the Enabling Act became law denounced both the proporients of the proposed legislation and the idea of uniform federal rules. ${ }^{2}$

In 1926, the Editor of the American Bar Association Journal declined to print a letter sent to him by Hall. In the letter, Hall noted he had not heard:

a single sound reason for this bill. Its sponsors say that it will promote uniformity, simplicity, speedier decisions and decisions upon the merits. As to whether it will promote speed and decisions upon the merits depends, of course, upon the second, that is, whether it will promote simplicity. Any consideration of the subject may, therefore, be confined to the two arguments of uniformity and simplicity. ${ }^{3}$

† Professor, Northeastern University School of Law. A.B. 1958, LL.B. 1963, Harvard University. I wish to thank my friend and colleague, Professor Judy Brown, for once again pruning with insight and humor. This article is adapted from a presentation given at the 50th Anniversary of the Federal Rules of Civil Procedure, held at Northeastern University School of Law, October 7-8, 1988.

1 On Walsh's opposition, see, e.g., Burbank, The Rules Enabling Act of 1934, 130 U. PA. L. Rev. 1015, 1063-65, 1081-95 (1982); Chandler, Some Major Advances in the Federal Judicial System 1922-1947, 31 F.R.D. 307, 481-82 (1963); Subrin, How Equity Conquered Common Law: The Federal Rules of Civil Procedure in Historical Perspective, 135 U. PA. L. REv. 909, 996-98 (1987).

${ }^{2}$ My claim for Hall's prescience is based on his ten-page letter. See Copy of manuscript of Connor Hall (Oct. 15, 1926) mailed to the Editor, American Bar Association Journal, requesting publication [hereinafter Hall], reprinted in Thomas $J$. Walsh Papers, Library of Congress, Box 302, Legislative File 1913-1933, "Procedure Bill" ca. 1926 [hereinafter Walsh Papers]. This manuscript was later published as Hall, Uniform Law Procedure in Federal Courts, 33 W. VA. L.Q. 131 (1927).

3 Hall, supra note 2 , at 1-2. The editor of the American Bar Association Journal at the time was Major Edgar B. Tolman, who later was appointed Secretary to the Supreme Court Advisory Committee. See Subrin, supra note 1, at 970-71. On Tol- 
Hall continued by asking why uniformity was desired in the district courts of the United States, stating, "[w]e should be shown in what way uniformity will promote justice. Unless it is to promote justice, then it is useless." "Hall further added that:

sponsors of the bill, however, speak of uniformity as if it were some excellence in itself, something transcendental and absolute; or at least as an undoubted blessing, as health, happiness or virtue. No reason is given why uniformity, if attained, would be of advantage to any litigant, though it might be to some lawyers. ${ }^{5}$

It is appropriate that we address Hall's questions about procedural uniformity during this fiftieth anniversary commemoration. Today we see a proliferation of local rules in federal district courts, ${ }^{6}$ the failure of half of the states to adopt the Federal Rules, ${ }^{7}$ and the acceleration of amendments to the Federal Rules. ${ }^{8}$ These factors compel exploration of the goals and implementation of interdistrict court and intrastate procedural uniformity. We must also examine another concept of uniformity: namely, the assumption that the same procedural rules should apply to all types of cases or, as Professor David Shapiro has cautioned, that the same options or uniform procedural smorgasbord be available for all types of civil suits. ${ }^{8}$ Case management, ${ }^{10}$ tracking systems, ${ }^{11}$ and the idea of a multi-door courthouse offering alternative

man's refusal to publish the letter, see Letter from Joseph R. Taylor, Managing Editor, to Hall (Oct. 29, 1926), reprinted in Walsh Papers, supra note 2. For Hall's spirited rejoinder to the rejection, see Letter from Hall to Mr. Joseph $\mathrm{R}$. Taylor (Nov. $10,1926)$, reprinted in Walsh Papers, supra note 2 . It ends: "It is of very little interest to me personally whether any of my views are published in the Journal, but it should be of great interest to you and the American Bar Association that its Journal be maintained as a genuine, honest, open forum." Id.

- Hall, supra note 2, at 2.

- Id.

- See infra text accompanying notes 98-116.

7 See infra text accompanying notes 152-54.

8 See, e.g., Burbank, supra note 1, at 1018-20; infra text accompanying note 122 (discussing the impact of the 1980 and 1983 amendments to the Federal Rules of Civil Procedure on the discovery process).

- In conversations with the author, Professor Shapiro has pointed out that true trans-substantive procedure would necessitate that each case have the same procedures; under the Federal Rules, lawyers are given leeway in many matters to decide which of the many Federal Rule procedures they choose to use. This is particularly true with respect to discovery. Even in a matter such as pleading, the Rules usually permit lawyers to decide how much of the story to tell. See, e.g., FED. R. Crv. P. 8(a) (requiring only a "short and plain" statement of a claim for relief).

${ }^{10}$ For discussion of case management, see generally Shapiro, Federal Rule 16: A

Look at the Theory and Practice of Rulemaking, 137 U. PA. L. REv. 1969 (1989) (examining whether Rule 16 has met the objectives of rulemakers).

11 See infra notes 207-09 and accompanying text. 
modes of dispute resolution ${ }^{12}$ are each a cause and effect of new thinking about "trans-substantive" uniformity. ${ }^{13}$ And all of these phenomena raise a final uniformity question: how can procedure most effectively aid the predictable application of substantive law and thus help to achieve uniformity of result in similar cases?

Connor Hall was correct. The proponents of the Enabling Act often talked of procedural uniformity as if it were a transcendental good whose inherent value required no explanation. The indefatigable A.B.A. propagandist for the Enabling Act, Thomas Shelton of Virginia, spoke of uniform federal procedure with religious fervor. ${ }^{14}$ When the proponents of the Enabling Act and the Federal Rules talked and wrote about uniformity they either explicitly or implicitly utilized several interconnected themes: efficiency, professionalization, federalism or nationalism, effective law application, power, and politics. ${ }^{15}$

Let us first look at the arguments advanced for uniformity and the responses of Thomas Walsh and Connor Hall. We will then examine the effect on procedural uniformity of federal local rules and state reluctance to adopt the federal rules. In doing so, we will rediscover the apparent intractability of problems in the search for a sensible procedural system, and the folly of "quick fix" procedural solutions. Moreover, there are other important lessons to learn for those who think that bringing the rule of fair and compassionate laws to bear on the human experience in a predictable and efficient manner is a worthy goal. The local rule and state divergence from procedural uniformity suggests that, without fanfare, we have already taken our first tentative steps into a new era in American civil procedure.

12 See generally Sander, Varieties of Dispute Processing, 70 F.R.D. 111 (1976) (discussing alternatives to conventional litigation).

13 Robert M. Cover used the term "trans-substantive" in Cover, For James Wm. Moore: Some Reflections on a Reading of the Rules, 84 YALE L.J. 718, 732-40 (1975) (discussing the benefits of and problems with applying a single set of procedural rules to a myriad of substantive claims). I do not recall seeing the term previously used.

14 For the part played by Shelton in the uniform federal rules movement, see Subrin, supra note 1, at 948-61. Shelton compiled many of his writings about courts and procedural matters in T. SHelton, SPIRIT OF THE CourTs (1918). Here is a typical statement by Shelton on the importance of uniform procedure: "Uniformity of legislation is a necessary convenience, but uniformity of administration is a fundamental necessity. . . ." Id. at 40.

15 Similar themes appear in the Field Code reform movement. See Subrin, David Dudley Field and The Field Code: A Historical Analysis of an Earlier Procedural Vision, 6 LAw \& Hist. REv. 311, 316-23 (1988). 


\section{The Many Faces of Uniformity}

\section{A. The Pro-Uniformity Argument}

Twentieth-century proponents of uniform federal procedural rules typically began by attacking the lack of uniformity caused by the Conformity Act of 1872 . The Act required (excepting equity and admiralty cases) that the civil procedure in each federal trial court conform "as near as may be" with that of the state in which it sat. ${ }^{16}$ Thomas Shelton and others argued that nonconformity existed because many federal procedural statutes and practices took precedence over conformity with state law; in such cases the federal judges correctly refused to apply inferior state procedures. ${ }^{17}$

The pro-uniform procedural rules advocates argued that the alleged nonconformity caused the following inefficiencies: 1) the waste in time and money of judges and lawyers trying to ascertain when in a particular federal district court to conform or not to conform to state procedure; $;{ }^{18}$ ) the time and expense of appealing such decisions; ${ }^{19}$ and 3) the cost to clients, particularly corporations engaged in interstate

${ }^{26}$ Act of June 1, 1872, ch. 255, §§ 5-6, 17 Stat. 196, 197. Shelton's 1911 A.B.A. resolution began: "Whereas, Section 914 of the Revised Statutes [the Conformity Act of 1872 ] has utterly failed to bring about a general uniformity in federal and state proceedings in civil cases . . . 37 A.B.A. REP. 434, 434 (1912); Burbank, supra note 1, at 1049 n.151.

${ }_{17}$ See, e.g., Report of the Committee on Uniform Judicial Procedure, 6 A.B.A. J. 509, 513-14, 525-27 (1920) [hereinafter 1920 Rep. Comm. Unif. Jud. Pro.]; Burbank, supra note 1, at 1067-68 ("From 1920 through 1929, the core of the ABA Committee's annual report remained the same from year to year."); McDowell, Some Misapprehensions as to Federal Procedure and Jurisdiction, 21 VA. ST. B.A. REP. 351, 370-71 (1908); Shelton, Uniform Judicial Procedure-Let Congress Set the Supreme Court Free, 73 Cent. L.J. 319, 321-22 (1911); see also A. Dobie, Handbook of Federal JURISDICTION AND PROCEDURE 584-88 (1928).

${ }^{18}$ See supra note 16; see also S. REP. No. 892, 64th Cong., 2d Sess. 2 (1917) [hereinafter 1917 SENATE REPORT].

That cases should be delayed month after month, and sometimes year after year, should be reversed and tried and retried, upon mere matters of practice that in no way touch the essential merits, is one of the reproaches in the administration of the law which has had a greater tendency to bring the practices of the courts into disrepute than any other thing.

Id.

19 Opponents of the Conformity Act often cited to the large number of procedural points that were dealt with on appeals. See, e.g., 1917 SENATE REPORT, supra note 18, at 3 ("T The time of the . . a appellate tribunals has been very largely taken up not in deciding the case but in endeavoring to ascertain the way to be followed in order to reach the point where a decision can be made at all."). One author mentioned the difficulty of federal circuit court judges in circuits that comprised many states, for under the Conformity Act they had to apply state procedure with which they had little familiarity. See Lile, Uniform Procedure at Law in the Federal Courts, 76 CENT. L.J. 214,214 (1913). 
commerce, of having to retain different lawyers or law firms in federal courts in different states, since experts on the state procedure were required. ${ }^{20}$

Shelton also argued that the state legislatures had amended state procedural statutes haphazardly. As a result, state court procedure, to which federal judges had to conform, was unduly complicated, unscientific and, "uncorrelated."21 In other words, the procedure governing each stage of litigation, such as pleading, joinder, and discovery, did not sensibly or efficiently relate to the other phases. $^{22}$

Shelton also made a more straightforward quality-of-justice argument, the importance of deciding like cases in a like manner, which he tied to the needs of the business community:

Commerce is the life blood of any country, the only measure of its prosperity and success, and the government that best maintains it, is best. Mindful of these things, it is with interest that one observes the organization and working of three great civil agencies looking to uniformity in statute, uniformity in procedure and uniformity in decision, all under the control of the American Bar Association. They are the "Conference of Commissioners on Uniform State Law," the "Committee on Uniform Judicial Procedure" and the "Interstate Conference of Judges." They give an assurance of interstate judicial relations as fixed, necessary and useful as fixed interstate commercial relations. ${ }^{23}$

Most proponents did not emphasize this "uniformity of result"

${ }^{20}$ See, e.g., Simplification of Judicial Procedure: Hearings Pursuant to S. Res. 552 Before the Subcomm. of the Senate Comm. on the Judiciary, 64th Cong., 1st Sess. 13-14 (1915) [hereinafter 1915 Senate Hearings] (Statements of Thomas Shelton).

${ }_{21}$ See, e.g., T. Shelton, supra note 14, at xxi-xxx. For examples of the frequent use of the word "correlated," see id. at 13, 33, 42; see also H.R. REP. No. 462, 63d Cong., 2d Sess. 13 (1914) [hereinafter 1914 House REPORT]; 1920 Rep. Comm. Unif. Jud. Pro., supra note 17, at 516.

${ }_{22}$ The assertion that the new uniform federal rule procedure would be "correlated" often accompanied an assertion or inference that legislative amendments to procedure, combined with the other sources of procedure, produced a bad result. See, e.g., 1914 House REPORT, supra note 21, at 13 ("It does not permit of argument that judicial procedure should be a complete, scientific, correlated system instead of a patchwork of disconnected statutes, decisions, rules, and common law."); see also 1920 Rep. Comm. Unif. Jud. Pro., supra note 17, at 516 (benefits to be achieved if uniform judicial procedure were adopted include court rule in lieu of statutory or common law procedure, allowing the foundation for fixed interstate judicial relations).

${ }^{23}$ T. Shelton, supra note 14, at 147-48; see also Shelton, An American Common Law in the Making-The Habit of Thinking Uniformity, 30 LAw Notes 50, 52 (1926) (arguing that "[t]here is no more excuse for differing judicial procedure than for differing languages in the several States"). 
theme. Perhaps, as we will see, this reluctance derived from the theme's tension with the simple and flexible rules the proponents also espoused. ${ }^{24}$

The commercial need rationale was usually linked to an argument that the states had become more interrelated by the telephone, telegraph, train, and airplane. ${ }^{25}$ A 1928 Senate Judiciary Committee Minority Report favoring uniform federal rules asserted that:

State lines have not to-day the persuasive force of a hundred or fifty years ago. The development of the economic resources of the country has brought with it problems that know no boundaries, and a growing consciousness of the commercial necessity for national uniformity both in law and its administration. ${ }^{28}$

Yet another aspect of the uniformity theme concerned professionalism and was inextricably bound to the efficiency, quality-of-justice, and nationalism arguments. The Enabling Act proponents believed that lawyers and judges were unfairly criticized because procedural law was so "unscientific" and confusing. They blamed the state legislatures, which continually passed unnecessary procedural amendments, and the federal Congress, which would not authorize the Supreme Court to pass a modern, uniform procedure. ${ }^{27}$ Further, Enabling Act proponents contended, the complex procedure permitted unethical lawyers, known as "procedural sharps," to take advantage of the system, further diminishing the profession's prestige. ${ }^{28}$ Several pro-Enabling Act enthusiasts even claimed that bad procedural rules caused some citizens to turn to Bolshevism. ${ }^{2 \theta}$

The professionalism theme included financial aspects. Lawyers who represented corporations which did business in several states could not with ease practice law in the federal courts of each state. ${ }^{30}$ Shelton

24 For a discussion of Shelton's shift from the theme of valuing fixed procedure because it constricts the discretion of judges and helps produce more predictable results to a position arguing for flexible procedure granting great discretion to judges, see Subrin, supra note 1 , at $949-61$.

${ }_{25}$ See, e.g., T. Shelton, supra note 14, at 29.

${ }^{26}$ S. REP. No. 440 , pt. 2, 70th Cong., 1st Sess. 10 (1928) [hereinafter 1928 SENATE REPORT]. 321-22.

${ }^{27}$ See, e.g., T. Shelton, supra note 14, at xx-xxix; Shelton, supra note 17, at

${ }^{28}$ See, e.g., 1915 Senate Hearings, supra note 20, at 12; 1914 House REPORT, supra note 21 , at 7 (quoting Senator Elihu Root). For a related theme, see generally Cockrill, The Shyster Lawyer, 21 YaLE L.J. 383 (1912) (examining the origin and present-day conception of the shyster).

${ }^{29}$ See Subrin, supra note 1, at 955 \& n.274, 959 \& n.290.

so See, e.g., 1915 Senate Hearings, supra note 20, at 14; T. Shelton, supra note 
bitterly complained that he could not even be admitted to practice in the federal courts of New York City: "[t]hese are what are called United States courts, but instead I call them New York City courts."31 Proponents also regretted that clients, particularly businessmen, were turning from courts to arbitrators, allegedly as a result of the procedural quagmire. ${ }^{32}$

The "uniformity" and "simplicity" arguments that Connor Hall placed at the heart of the pro-Enabling Act position were interrelated. The lack of uniformity of procedure in federal courts exemplified the lack of simplicity. ${ }^{33}$ Another example was that in federal court one applied Federal Equity Rules to equity cases, while on the law side one applied the hodgepodge of state-federal procedural law. ${ }^{34}$ Uniform federal rule enthusiasts cited statistics of the high percentage of procedural issues on appellate dockets, asserting that procedure kept substantive law from being applied. ${ }^{\mathbf{3 5}}$

Uniform, simple procedural rules for the federal courts implies centralized rulemaking. Proponents blamed legislatures for the present unsatisfactory scheme. They contended that some expert and trusted body_such as the Supreme Court ${ }^{36}$ - should be entrusted with the task of drafting simple rules. Shelton ironically spoke about the "sublime faith" that "abides in people of this country" for what he called "their highest tribunal,"37 at a time when many Americans viewed the Court as an obstacle to social legislation passed for their benefit. ${ }^{38}$

Choosing the Supreme Court as rulemaker led proponents to the argument that the Enabling Act, unlike the Conformity Act, would re-

14 , at 33-34.

311915 Senate Hearings, supra note 20, at 13.

32 See Subrin, supra note 1, at 960 n.295.

33 See, e.g., 1917 SENATE REPORT, supra note 18, which starts with criticism of the Conformity Act, and ends:

If this bill shall be passed, the Supreme Court will adopt rules of so simple and workable a character that they will constitute models for the various States, with the result that in the course of a few years we shall have a uniform system of simple procedure in operation in all the courts of the country, Federal and State, alike.

The title of the Report was "Simplification of Judicial Procedure in Federal Courts." ed. 1947).

See, e.g., C. Clark, Handbook of the Law of Code Pleading, 31-34 (2d

35 See, e.g., 1917 Senate Report, supra note 18, at 3-4; T. Shelton, supra note 14 , at $257-59$.

${ }^{38}$ See 1917 SENATE REPORT, supra note 18, at 6; supra note 27 and accompanying text.

${ }^{37}$ T. Shelton, supra note 14 , at 35.

38 See, e.g., 2 H. Pringle, The Life and Times of William Howard Taft 572-74 (1964); 17 T. Roosevelt, The Works of Theodore Roosevelt 5-22 (National ed. 1926) (speech at Osawatomie, Kansas, Aug. 31, 1910). 
sult in intrastate uniformity. The Supreme Court would promulgate such sound and simple rules that each state would copy them. ${ }^{38}$

Concerns about uniformity also raised issues about the relationship between procedure and substance. It is logically possible that one could have the same procedural rules in all federal courts, but that those rules would not be trans-substantive. There could be different procedural rules for different substantive cases. For example, the pleading requirements required in antitrust cases might differ from those in automobile tort suits.

Under the evolving uniformity and simplicity ideology such a nontrans-substantive procedural methodology could not develop. A bias against procedural linedrawing inhered within the system. It was thought that definitional or confining procedure caused needless disputes over distinctions and lines, and interfered with cases getting heard on the merits. ${ }^{40}$ Also, a scheme attempting to integrate substance and process would imply a relationship between the two which would have made it difficult to persuade Congress to confer such power upon the courts. This was especially true from 1911 through 1930 when Enabling Act proposals were presented to the Senate Judiciary Committee, many of whose members distrusted the conservative Supreme Court. ${ }^{\mathbf{4 1}}$ Finally, the Supreme Court could not, particularly in a brief period, have drafted non-trans-substantive rules. That task would have required extensive hearings and reflection to try to mesh procedure and substance. It would have raised sensitive political questions concerning the rationale for applying different procedure to different types of cases.

This "uniform federal rules" theme ended up with four strands: interdistrict court uniformity, intrastate uniformity, trans-substantive uniformity, and, although this was not stressed, uniformity of result. 33.

39 See, e.g., 1920 Rep. Comm. Unif. Jud. Pro., supra note 17, at 516; supra note

40 See Subrin, supra note 1, at 961-65 (discussing the procedural views of Charles E. Clark, the Reporter of the Supreme Court Advisory Committee that drafted the Federal Rules).

41 Senator Walsh, a member of the Senate Judiciary Committee throughout this period, was instrumental in defeating Enabling Act bills for two decades. See supra note 1 and accompanying text. He included the conservative nature of the Supreme Court as an argument against the uniform federal procedural bill. See e.g., Views of the Minority from the Senate Comm. on the Judiciary, S. REP. No. 892, 64th Cong., 2d Sess. pt. 2, at 5 (1917) [hereinafter 1917 SEnate RePort, Part 2] ("The Supreme Court of the United States is, by its very constitution, conservative . . . [T] have [no] opportunity, from their own experience and observation, to know whether the system as a whole or in any detail works satisfactorily or not."). 


\section{B. The Walsh-Hall Critique}

Thomas Walsh, the progressive Democratic senator from Montana, was the chief opponent of uniform federal rules from 1912, when he was elected Senator, until his death in $1933 .{ }^{42}$ Walsh never conceded the failure of the Conformity Act. He thought conformity with state procedural law worked quite well for the vast majority of lawyers, and was certainly better than uniform federal rules which would require lawyers to learn two sets of procedures-one for federal court and one for state..$^{33}$

Walsh was perhaps correct that the Conformity Act did not lead to the quagmire that the pro-uniformity forces claimed. During the $1880 \mathrm{~s}$, when David Dudley Field and others proposed a uniform federal procedural rules reform, many who resisted maintained that the Conformity Act worked properly and aided local lawyers. ${ }^{44}$ Walsh, who had been a successful trial lawyer in Montana, contended that although there were occasions when federal judges chose not to conform to state procedure, the exceptions were predictable and well known to the bar. ${ }^{45}$ In 1926, he took an informal poll of federal judges. Of the forty clearcut responses, twenty-six, or sixty-five percent, favored the Conformity Act over the Enabling Act proposal. ${ }^{46}$

Walsh further argued that the pro-uniform rules enthusiasts developed their "simplicity" argument only after their uniformity argu-

12 See sources discussed supra note 1 . Ironically, Walsh's death in 1933, after Franklin Delanor Roosevelt had selected him to be Attorney General, permitted Homer Cummings to succeed him. Cummings subsequently resurrected the Enabling Act bill. See Burbank, supra note 1, at 1095-96.

${ }^{43}$ See 1915 Senate Hearings, supra note 20, at 27 (statement of Thomas Walsh, quoting from a speech given at a Montana Bar Association meeting); see also, Simplification of Judicial Procedure in Federal Courts: Hearing on S. 1011, 1012, 1546, 2610, and 2870 Before a Subcomm. of the Senate Comm. on the Judiciary, 67th Cong., 2d Sess. 15 (1922) [hereinafter 1922 Senate Hearings] (Statement of Thomas Walsh); Walsh, Reform of Federal Procedure, Address Delivered at Meeting of TriState Bar Assn. at Texarkana, Ark.-Tex. (Apr. 23, 1926), reprinted in S. Doc. No. 105, 69th Cong., 1st Sess. 1-2 (1926) [hereinafter Walsh, Texarkana Address] (also attached to S. REP. No. 440, 70th Cong., 1st Sess. 2-15 (1928)); Walsh, Rule-making Power on the Law Side of Federal Practice, 13 A.B.A. J. 87, 87 (1927) [hereinafter Walsh, Rule-making] (address given at the annual meeting of the Oregon Bar Association).

44 See Subrin, supra note 1, at 943 n.200.

45 See e.g., 1922 Senate Hearings, supra note 43, at 15-16 (Walsh) ("[Under the Conformity Act the state court practitioner] has only a very little to learn in order to be equally skillful in the Federal court."); Walsh, Texarkana Address, supra note 43, at 3 ("[I]n most instances the inapplicability [of state procedure] is perfectly obvious.").

${ }_{18}$ See Subrin, supra note 1, at 958 n.284; see also 38 A.B.A. REP. 34-44 (1913) (comments of Moorfield Storey of Massachusetts and Warren E. Lloyd of California speaking against an ABA-sponsored uniform rules bill, indicating that in 1913 the lack of conformity was not a big problem; others who spoke disagreed). 
ment had "proven fatally weak."47 They were, Walsh suggested, primarily seeking to replace an intrastate uniformity that helped most lawyers with an interstate uniformity in federal courts, which would help only the few lawyers who practiced in the federal courts of more than one state. Walsh applauded the uniform state laws movement, but denied that procedural uniformity would aid substantive uniformity. ${ }^{48}$ The notion that the new procedure would be simple and interpretationfree was "utterly chimerical." beyond human ingenuity or talent to frame statutes or rules suited to every contingency expressed in language concerning the interpretation of which no controversy of substance may arise."

Walsh doubted that flexible equity rules were simple for the practitioner, and rejected the position that they should form a model for procedure in all cases. He pointed out that equity practice required lengthy treatises and a trial bar that specialized in equity suits. ${ }^{51}$

Walsh thought that Field had done a remarkable job, and that the Code worked well in Montana, but he noted that many states had not agreed. He believed it was unlikely, therefore, that all states would agree to follow a new set of federal rules. ${ }^{52}$ Conditions around the country varied and different regions needed different procedures. Moreover, according to Walsh, there were many important procedural matters about which there would not be national agreement. ${ }^{53}$

After a trip to England, Walsh concluded that culture and manners influenced the efficiency with which lawsuits were processed more than did procedural rules. For instance, he attributed the relative speed of English litigation to the practice of announcing rulings immediately from the bench, as well as the reluctance of English judges to countenance delay. ${ }^{\mathrm{si}}$

471917 Senate RePort, Part 2, supra note 41, at 2-3.

48 See Walsh, Texarkana Address, supra note 43 , at 8 ("I inquire again, what is the substantial gain to be anticipated from this departure [from state procedure]?").

40 See 1917 Senate RePort, Part 2, supra note 41, at 4; see also Walsh, Rulemaking, supra note 43, at 89 ("[Field] advocated the adoption of a new system of simple rules that no one could misunderstand and he believed that out of it no questions of practice could conceivably arise. Now that idea is perfectly chimerical.").

so Walsh, Texarkana Address, supra note 43 , at 3.

51 See 1915 Senate Hearings, supra note 20, at 12; Walsh, Texarkana Address, supra note 43 , at 5 .

52 See Walsh, Texarkana Address, supra note 43, at 8.

${ }^{53}$ See id. at 6-8 (citing as examples limitations of actions, provisional remedies, and jury selection); Walsh, Rule-making, supra note 43 , at 90 .

54 See Walsh, Texarkana Address, supra note 43, at 11-13 (citing as examples that English lawyers rarely object to the admission of evidence and that juries usually consist of the first 12 persons called); Letter from Thomas Walsh to Mr. and Mrs. Hutchens (Oct. 5, 1925), reprinted in Walsh Papers, supra note 2 (concluding that "it is the habits of our bar that need reforming, not the laws under which they act"). 
Walsh thought that the Supreme Court had neither the time nor the institutional competence to draft uniform rules for all trial courts. $\mathrm{He}$ argued that the Justices were conservative and old, and far removed from both the populace and from the trial courts. He further believed that enactment of procedural rules was properly a legislative and not a judicial function..$^{\mathrm{s5}}$

Connor Hall, a West Virginia lawyer, used several of Walsh's arguments, ${ }^{5 B}$ but he added speculative and jurisprudential arguments eschewed by the more practical politician. Hall predicted the impact of the proposed "reform" upon the profession.

[A] firm in a great city may represent a railroad, or an industrial company doing business in many states[;] if the procedure in the Federal Courts is uniform this city firm can, itself, conduct the main parts of the litigation and reduce the local lawyers substantially to filing clerks and advisors on jurors. Uniformity, therefore, increases the influence and importance of the great city firm, having at its head, perhaps, some business man masquerading as a lawyer, with his partners of first and second magnitude, law clerks, process servers, runners, etc.; would correspondingly reduce local practice, local ability and local pride and drive the practice of law further on the downward road from a profession to a business. . . . Uniformity would further augment the importance of large aggregations of men and depress the individual. ....57

Hall gave several reasons why uniform federal rules would not result in a uniform procedure. He noted how the idea of general, non-

Walsh also pointed out how small England is relative to the size of the United States. See Walsh, Texarkana Address, supra note 43, at 6 ("half that of the state of Montana").

b5 See 1917 Senate Report, Part 2, supra note 41, at 5-6; Walsh, Texarkana Address, supra note 43,9-10 (arguing that if the task had to be given to the judiciary, district judges were the better choice). But see Walsh, Rule-making, supra note 43 , at 91:

Now I want it distinctly understood that I am making no argument whatever against the system of rules prescribed by a court [of a single state] as against laws enacted by the legislature. If the people of the state of Oregon believe that the Supreme Court of the state of Oregon can more wisely act upon such a matter than can their legislature, I shall have not fault to find.

${ }^{\text {ss }}$ See Hall, supra note 2, at 4, 6-7, 9.

s2 Id. at 2. 
rigorous, "simple" rules was at odds with true uniformity.

[I]f the rules are not to make provision for the various contingencies of litigation, but are to be exceedingly simple, questions would be continually arising before the District Judge for which there was no rule.

We can not ignore the fact that questions, and numerous, will arise. . . . How will the District Judge decide? By what will he be guided? The answer is not doubtful. He will turn to the system in which he has been trained and with which he is already familiar, to-wit, the State practice. . . . At the end of, say a generation, the practice would probably have reached about the same conformity with State practice as is now observed. ${ }^{58}$

Moreover, in Hall's view, uniformity of equity procedure in England and the federal courts occurred not because of rules, but because uniform practices already existed when the Equity Rules became law. ${ }^{59}$ Hall noted that the size and diversity of America, compared with England, made uniformity difficult to achieve. ${ }^{60}$

Hall was most perspicacious when he discussed the nature of procedure and its relationship to the concept of "simplicity," cautioning that using rules to achieve simplicity and lack of technicality "is a willo'the wisp."

All sorts of questions will, and do, arise in the course of litigation, and we can not avoid them by pretending that they do not exist. Many of these questions, perhaps, are not important, but some are important. Even so, in hotly contested litigation the unimportant ones will be pressed, and certainly the important ones are effective in a very practical way upon the substantive right. It is futile to pretend otherwise. ${ }^{61}$

Hall did not understand how the proponents of uniform rules thought they could reduce procedural problems just by changing the rules. He declared:

Practice is a mere tool, but in any system of government, having anything like a guaranty of private rights and a judiciary of integrity and consistency, there must be a way to bring causes to the attention of the court; to adduce proof; to

${ }^{61}$ Id. at 4. 
bear argument; to conclude the cause; to give the proper judgment; to take the proper steps for enforcing it . . . . Jack Cade (or can it possibly be Jack Code?) thought all of this was very easy and that lawyers were merely perverse, but any lawyer knows that it is difficult and often necessarily intricate and complicated. We can not ignore the importance of a settled and fair procedure. . . . Stability, even in procedure, is highly desirable. It is a maxim that nothing is worse than variable and uncertain law. ${ }^{62}$

Senator Thomas Walsh and lawyer Connor Hall have left us with a legacy. Hall was skeptical of interdistrict court uniformity because of the nature of the federal judiciary and the inevitable gaps that appear in general, simple rules. He was certain that faced with such generality, judges would fall back upon their local experiences. Walsh was skeptical of interstate uniformity, not only because of the nonuniversal adoption of the Field Code, but also because of the variations among different regions and traditions. Both thought that the underlying legal culture was more important to procedural simplicity and uniformity than were the rules themselves. Both were certain of the difficulty of enacting codes that would materially decrease the need for interpretation. Neither thought equity rules and practice were as simple and easy to apply as the proponents said. Walsh, particularly early on, questioned the competence of the Supreme Court to make procedural rules for the trial courts. Hall insisted that procedural rules can be critical to substantive results.

It is within the context of these predictions that we examine the theme of uniformity, and its companion, simplicity, fifty years after the Federal Rules became law.

\section{Local Rules: Wild Flowers in the Garden}

\section{A. Drafting Rule 83: the Local Rules Provision}

In the original version of the Federal Rules, Rule 83 provided:

Each district court by action of a majority of the judges thereof may from time to time make and amend rules governing its practice not inconsistent with these rules. . . . In all cases not provided for by rule, the district courts may regulate their practice in any manner not inconsistent with 
these rules. ${ }^{63}$

This crack in the wall of uniformity has become a gaping hole.

District court local rulemaking power had been explicitly granted to the trial courts from their birth in 1789 until $1872 .{ }^{64}$ The Conformity Act of 1872 reflected Congress's desire to severely limit this power. The requirement of the Act to conform to state practice was followed by the proviso, "any rule of court to the contrary notwithstanding "65

Despite the "notwithstanding" clause, letters sent to the advisory committee in 1935 imply that local rules under the Conformity Act had become an important part of the procedural landscape. Commentators disagreed about the extent to which this should continue under the new Enabling Act. For example, a judge of the Southern District of New

${ }^{63} 308$ U.S. 765 (1939) (setting forth rule as promulgated in 1938). The rule has been supplemented over the years, but this language remains unchanged.

At the time of the adoption of the Federal Rules, district courts were already authorized by statute to make local rules not inconsistent with law or with any rule prescribed by the Supreme Court. See 28 U.S.C. $\$ 731$ (1934). This, and similar sections dealing with other United States courts, are consolidated in the current section 2071, which provides: "The Supreme Court and all courts established by Act of Congress may from time to time prescribe rules for the conduct of their business. Such rules shall be consistent with Acts of Congress and rules of practice and procedure prescribed by the Supreme Court." 28 U.S.C. $§ 2071$ (1982).

This statute was supplemented by the Judicial Improvements and Access to Justice Act, Pub. L. No. 100-702, $\S 403,102$ Stat. 4642, 4650-51 (1988), to require "appropriate public notice and an opportunity for comment" before rules are prescribed, and to subject rules prescribed by district courts to review by the judicial council of the relevant circuit to ensure consistency with the Federal Rules.

${ }_{64}$ See J. Weinstein, Reform of Court Rule-making Procedures 117 (1977).

${ }_{65}$ Act to Further the Administration of Justice, ch. 255, § 5, 17 Stat. 196, 197 (1872). However, there continued in statute the language that became 28 U.S.C. $\S 731$ (1934), providing that:

The district courts may, from time to time, and in any manner not inconsistent with any law of the United States, or with any [equity] rule prescribed by the Supreme Court . . . make rules and orders directing the returning of writs and processes, the filing of pleadings, the taking of rules, the entering and making up of judgments by default, and other matters in vacation, and otherwise regulate their own practice as may be necessary or convenient for the advancement of justice and the prevention of delays in proceedings.

According to Professor Armistead M. Dobie, who was on the original advisory committee:

The Conformity Act and this rule-making statute must be construed together. Though the Conformity Act ends with the phrase "any rule of the court to the contrary notwithstanding," it is quite clear that the power of the District Courts to make rules on the subjects mentioned in the rulemaking statute is not nullified by the Conformity Act.

A. DoBIE, supra note 17 , at 587. 
York wrote: "I trust that the Supreme Court will construe the [Enabling Act] statute as entitling the district courts to make local rules adapted to the needs of their several communities." But an Indiana committee suggested "[t]hat the field left to local rules be definitely delimited." A South Dakota district court judge wrote: "I recognize the desirability of the uniformity of the procedure in the several District Courts and believe practically all procedural matters should be covered by general rules, [and] local rules should be reduced to a minimum."

The drafts and deliberations of the advisory committee show that the drafters saw a necessity for local rules to meet local conditions and for some body of law to fill the gaps not covered by the Federal Rules. The first draft prepared by Charles Clark, the reporter, suggested that the committee consider whether local rules could not only supplement the Federal Rules, but also change them. He explained: "Some such provision affording flexibility to the rules is necessary if they are to be adjusted easily and without friction to the differing habits and customs of lawyers throughout the country."

During the deliberations, committee members initially had two assumptions: first, that the Federal Rules, plus local rules, would cover most procedural areas, and second, a rule providing what law would apply if neither covered a subject was needed. The local rules were to cover the "machinery of running" the court. ${ }^{68}$ A second draft stated that any areas not covered by statute, the Federal Rules, or local rules "shall be governed by the common law as developed and applied in the federal courts." guage, and/or the use of state or equity practice to cover the residue. Clark feared that reference to state law in the residuary provision

${ }^{68}$ Suggestions of Local Committees and Suggestions of District Judges, as compiled by the Secretary of the Advisory Committee and furnished to members to accompany Tentative Draft (Oct. 15-16, 1935), contained in looseleaf binder entitled Advisory Committee on Rules for Civil Procedure, Tentative Draft 1 (Oct. 15-16, 1935) [hereinafter T.D. I] in Harvard Law School Library. This binder and other original documents pertaining to the work of the advisory committee were donated to Harvard by Committee member Edmund M. Morgan, and are referred to collectively as Morgan Papers hereinafter. For other sources of original papers relating to the Federal Rules, see Burbank, supra note 1 , at 1132 n.529.

67 T.D. I, supra note 66 (Note to Rule 3).

686 Proceedings of Meting of Advisory Committee on Rules for Civil Procedure 1515 (Feb. 20-25, 1936) [hereinafter Proceedings on Rules] (Lemann, quoting Donworth); see also id. at 1514 (Edmund Morgan) ("The mechanics, as they call it."). Members of the advisory committee also used this term to cover matters that had not been reached by the Conformity Act, or by federal statutes. Former Justice Olney of the California Supreme Court thought that "[a] good deal must be left to the local court, in the way of regulating its own procedure." Id. at 1516-17.

${ }_{68}$ Tentative Draft II (Dec. 26, 1935) [hereinafter T.D. II], in Morgan Papers, supra note 66 (Rule A38) (binder). 
might lead to a rebirth of Conformity Act thinking. The committee voted to delete the "common law as developed and applied in the federal courts" residuary clause. ${ }^{70}$

In a revised draft of February, 1937, Clark tried to solve both the local rules and residuary clause issues by adopting the suggestion of a Massachusetts committee to place residual power in each federal district court, ${ }^{71}$ as was the case under the admiralty rules. Clark's draft read: "In all cases not provided for by such rules, the district courts may regulate their practice in such manner as they deem most expedient for the due administration of justice but not in any manner inconsistent with these rules." ${ }^{\prime 2}$ In April, the Style Committee changed the language slightly to the phraseology ultimately adopted in the last line of Rule 83: "In all cases not provided for by rule, the district courts may regulate their practice in any manner not inconsistent with these rules."73

Thus, Clark and the Advisory Committee ended up with a fairly broad local rule provision in terms of coverage and the residue. ${ }^{74}$ Moreover, Clark's initial controls on local rule power were eliminated. Clark's first draft stated:

Each district court, by action of a majority of the judges thereof, may establish further rules of practice and procedure governing civil actions in its district, supplementary to these rules, for the purpose of effectuating a simple and efficient

70 See Proceedings on Rules, supra note 68, at 1508-18 (voting on lines 8-11 of Rule A38, Statutes and Former Rules of Practice to Apply When); see also T.D. II, supra note 69, at 2 (Note on Rule A38) (Clark pleading for his residuary clause: "Now that we are rid of the Conformity Act, let us stay rid of it.").

${ }^{71}$ See Preliminary Draft 3 (Feb. 1937) [hereinafter P.D. 3], in Morgan Papers, supra note 66 (Rule 92, Rules by District Courts) (binder). For copy of portion of letter from the Massachusetts Committee, see T.D. I, supra note 66 (suggestions of local committees on Rule 3).

${ }_{72}$ P.D. 3, supra note 71 (Rule 92).

92) (binder).

${ }^{73}$ Style Committee Draft (Apr. 1937), in Morgan Papers, supra note 66 (Rule

${ }^{74}$ This is not even a true residuary clause, because there is no mandatory backstop in the absence of other law. All that Rule 83 stated was that the district courts had the authority to decide in the interstices left by noncoverage. I presume that individual district court judicial discretion, exercised either on a case-by-case basis or through standing orders, is the ultimate residuary under this scheme, for no other is provided. Apparently, though, the advisory committee did not anticipate the large number of standing orders issued by individual federal judges that now exist. It was evidently assumed that a single judge could not make her own local rule when there was more than one judge in a district. One committee member (Lemann) pointed out that "[y]ou would always want a majority of the district judges, where there was more than one district judge. That ought not to be bracketed." (Brackets were used to show alternative drafts to present to the Supreme Court.) Clark replied, "All right." ProceEdings on RuLES, supra note 68, at 1504. 
procedure, provided, however, that such rules must be approved before becoming effective by the Supreme Court of the United States, upon recommendation of its Advisory Committee on Civil Procedure . . . .

His note made clear that "all discussion in support of the rulemaking power recognizes continuing supervision of the rules as essential."76

Clark's second draft offered three alternative rules for controlling the local rulemaking power: first, the "majority of the circuit judges for the circuit" would be required to concur with a district court's local rulemaking; or second, a majority of judges in a district could act on their own; or third, the Supreme Court - and here there were two sub-versions - would have to "approve" or "may amend or abrogate" local rules. ${ }^{77}$

Committee deliberations revealed political problems. Under the Equity Rules of 1912, the circuit courts had supervisory power over district court rulemaking; the committee did not want to engage in a battle between circuit and district court judges. ${ }^{78}$ Former Senator Pepper of the committee quipped: "We do not want to get our fingers in the crack of the judicial door." Committee members were also concerned that by suggesting the need for a supervisory body they would be perceived as trying to perpetuate their own power. ${ }^{80}$ They decided to give the Supreme Court alternative proposals concerning authority over local rules. ${ }^{81}$ Although Clark preferred to vest this power in the Supreme Court with the advice of an advisory committee, the committee rejected that proposal..$^{82}$ Later drafts gave only two alternatives: by the action of a majority of a district's judges or, the same majority "with the concurrence of a majority of the circuit judges for the circuit."

The final version of Rule 83 provided that a majority of the judges in each district could make local rules for their court so long as those rules were not inconsistent with other law. There was no provision for a supervisory body. Just as the "near as may be" language in the Con-

${ }^{76}$ T.D. I, supra note 66 (Rule 3) (bracketed matter omitted).

${ }^{78} I d$. (note to Rule 3).

77 T.D. II, supra note 69 (Rule A37).

78 See Proceedings on Rules, supra note 68, at 1495-97, 1502-04.

79 Id. at 1503.

${ }^{80}$ See id. at 1498-1508.

${ }^{81}$ See id.

82 For Clark's probable preference, see T.D. II, supra note 69 (Note to Rule A37); Proceedings on Rules, supra note 68, at 1498-1500 (Clark speaking for a permanent advisory committee and for giving the Supreme Court control over local rules). (binder).

${ }^{83}$ Tentative Draft III (Mar. 1936), in Morgan Papers, supra note 66 (Rule A43) 
formity Act had previously resulted in federal courts not following state procedure, Rule 83 might be expected to result in material nonuniformity among district courts under the emerging new scheme.

\section{B. The Knox Committee Report: 1940}

No sooner had the Federal Rules become effective in September, 1938, then the Judicial Conference of Senior Circuit Judges appointed a committee of district court judges "to examine the various rules of the District Courts and to make recommendations so that the greatest practicable degree of uniformity throughout the country should be secured." its chairman, District Judge John C. Knox of the Southern District of New York. The Conference's instructions to the Committee stressed simplicity: "In the amendment of the rules of the respective District Courts it is important that regard should be had to simplicity. It is the sense of the Conference that these rules should be made in the spirit which has governed the adoption of the new procedure; the rules should be few, simple, and free from unnecessary technicalities."8s

Although the 1940 Knox Committee Report does not quantify the number of local rules then existing, there were clearly enough to concern the conference and the committee about impairment of uniformity. To combat what we now call "local rule proliferation," they argued that "very few local rules are now really indispensable" and that "[u]nless experience demonstrates a pressing need for additional local rules, none should be promulgated."

The charge to the committee had noted that the Federal Rules required changes in the district court rules. ${ }^{87}$ But the committee found that many local rules that pre-dated the Federal Rule and were in conflict had been retained. ${ }^{\mathbf{8}}$ Even worse, analysis of rules adopted in 32 districts since September 16, 1938 showed that:

[A] few of the new local rules have unnecessarily repeated provisions of the Federal rules or attempted to restate the effect of those provisions in different language. Others cover ground upon which the Federal rules are intended to be complete. Others attempt to lay down rigid details to imple-

84 Report to the Judicial Conference of the Committee on Local DisTRICT Court Rules III (1940) [hereinafter KNOX Committee RePoRT].

ss $I d$. at 1 n.1.

${ }^{86} I d$. at 2-3.

${ }^{87}$ See id. at 1, n.1.

${ }^{88}$ See id. at 10. 
ment or supplement the Federal rules in minor particulars which had been deliberately left unregulated because of the belief that the method of dealing with them could be best determined in individual cases as the problems arise. Some apparently overlook specific contrary provisions of the Federal rules. Rules such as these, which create inconsistencies in practice among the various districts and leave doubt and uncertainty in the minds of the bench and bar, are likely to prove to be serious impediments to national uniformity. They tend to defeat the simple general system of procedure which the Federal rules were intended to establish for all district courts. ${ }^{89}$

At the same time, the Report acknowledged that some local rules were appropriate. Its first major conclusion was that varying local conditions made "absolute uniformity in the local rules of the district courts . . impracticable and inadvisable." ${ }^{\text {90 }}$ Local policies were particularly relevant to rules on admission of attorneys to practice, calendaring of motions, and assignment of cases for trial.91

The Report noted differences among urban and rural districts that might necessitate different rules, suggesting that some urban courts, "feel that they must protect themselves from inexperienced, incompetent, and unfit practitioners." 92 The number of judges and size of territory covered by districts influenced calendar and assignment issues. ${ }^{93}$ The Knox Committee further noted that the Federal Rules themselves had specifically left five areas to "supplemental regulation by local

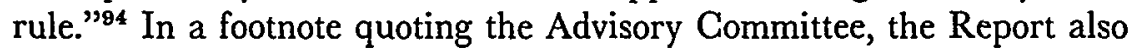
predicted that local rules would prove helpful in suggesting future amendments to the Federal Rules-an early recognition of the experimentation value in permitting local rules. ${ }^{95}$ The Report mentioned sev-

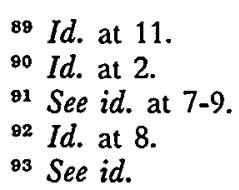

94 Id. at 9 n.4 ("They are: (1) pre-trial calendars (Rule 16), (2) trial calendars (Rules 40 and 79(c)), (3) administration of estates by receivers (Rule 66), (4) motion days and submission of motions on brief (Rule 78), and (5) court stenographers (Rule 80).").

${ }_{95}$ See id. at 13 n.5 (citing 59 DeP'T J. Bull. of Decisions on FRCP 1-4 (Jan. $17,1940)$ ). For current discussions of the experimentation value of local rules, see Flanders, Local Rules in Federal District Courts: Usurpation, Legislation, or Information?, 14 Loy. L.A.L. REv. 213, 269-70 (1981) [hereinafter Flanders, Local Rules]; Flanders, In Praise of Local Rules, 62 JudicatuRe 28, 31 (1978) [hereinafter Flanders, In Praise]. 
eral subjects of local rules it thought inappropriate. ${ }^{96}$

More importantly, notwithstanding protestations that some courts needed no local rules, the Knox Report contained a twenty-five page appendix entitled "Suggested Local Rules for United States District Courts." It provided rules on nine different topics, with twenty-eight subtopics. Model rules were provided for bar admission, bar discipline, and for several phases of litigation. However, the committee members acknowledged that some districts might need more or fewer rules, and if any court should find "the provision proposed is not suited to the particular situation in that district, the necessary departures from the proposed form should be freely made."97

\section{Fifty Years Later}

The Knox Report appeared in 1940, at the height of the euphoric notions that under the new uniform Federal Rules, any lawyer could go to any federal court, and be secure that she could understand and master the procedure required, since that procedure would be at once uniform and simple. ${ }^{98}$ Developments since have not borne out those hopes. The reasons for local rule proliferation have probably multiplied. The number of cases in the federal courts has risen dramatically, and cases may have become far more complex than the drafters of the Federal Rules anticipated.99 Discovery and documentation is often vast. ${ }^{100}$ Many federal judges feel compelled to manage their dockets and to routinize operations; some feel a need to control the behavior of the large numbers of new lawyers who join the bar each year. ${ }^{101}$ Court.

${ }_{96}$ These include selection of jurors, details of courtroom conduct, verification of pleadings, and details of internal court administration. It also noted some districts had rules on bankruptcy and stenographers, but these were deferred for future study. See KNOX COMMITTEE REPORT, supra note 84, at 16-20.

${ }^{97}$ Id. at 14-15.

98 See, e.g., Federal Rules of Givil Procedure Proceedings of the Institute at Washington, D.C. and of the Symposium at New York City 28 (1939) [hereinafter Proceedings].

${ }_{99}$ See, e.g., R. Posner, The Federal Courts app. B, table B-2 at 350-52 (1985) (showing civil case filings in federal district courts rose from 33,591 in 1938 to 96,056 in 1973 and 241,159 in 1983); Burger, Annual Report on the State of the Judiciary-1980, 66 A.B.A. J. 295, 297 (1980); Renfrew, Discovery Sanctions: A Judicial Perspective, 67 GAlif. L. REv. 264, 275 (1979).

100 See, e.g., Sherman \& Kinnard, Federal Court Discovery in the 80's-Making the Rules Work, 95 F.R.D. 245, 246 nn.1-2 (1982) (reporting complaints about overuse of discovery).

${ }_{101}$ See, e.g., Burger, supra note 99 , at 295-96 (noting changes in judicial administration to deal with increased case loads, and commenting on the need for increased emphasis on professional ethics in legal education); Costantino, Judges as Case Managers, TRIAL, Mar. 1981, at 56 (proposing a methodology for efficient case management by judges); Elliott, Managerial Judging and the Evolution of Procedure, 53 U. CHI. 
personnel have increased: there are more judges, clerks, administrators, and new federal judicial officers called magistrates. ${ }^{102}$

Perhaps because there is no consensus, Congress and the Judicial Conference repeatedly try to solve problems by leaving important questions to local rules. At least thirty-nine provisions of Titles 12, 18, 22, $26,28,42,46$, and 50 direct, authorize, or result in local rulemaking. ${ }^{103}$ During the past twenty years, the Judicial Conference has made resolutions or recommendations directing or suggesting local rulemaking on at least forty occasions. ${ }^{104}$ Federal Judicial Center publications, Judicial Council recommendations, and the Office of Audit and Review of the Administrative Office of the United States Courts have all, on occasion, suggested local rules to all or selected federal trial courts. ${ }^{105}$

In 1983, the House Subcommittee on Courts, Givil Liberties, and the Administration of Justice of the House Judiciary Committee examined the proliferation of local rules. ${ }^{106}$ A 1985 Judiciary Committee report noted the benefits of local rules (accommodating local conditions, communicating required practices to the bar, and ridding the court of routine tasks), but also identified several problems concerning local rules, such as their promulgation without sufficient input, the tremendous numbers of such rules, and the frequent conflict between local

L. REv. 306 (1986) (discussing the meaning and functions of managerial judging and assessing its effectiveness); Peckham, The Federal Judge as a Case Manager: The New Role in Guiding a Case from Filing to Disposition, 69 Calif. L. Rev. 770 (1981) (discussing pre-trial case management by judges); Resnik, Managerial Judges, 96 HARv. L. REv. 374 (1982) (describing managerial judging and expressing concerns about the emergence of judicial case management); Richey, A Federal Trial Judge's Reflections on the Preparation for and Trial of Civil Cases, 52 IND. L.J. 111, 117-24 (1976) (setting forth Judge Richey's standard pre-trial order); Schwarzer, Managing Civil Litigation: The Trial Judge's Role, 61 Judicature 401 (1978) (discussing pretrial case management by judges).

102 See R. PoSNer, supra note 99, at 97; Silberman, Judicial Adjuncts Revisited: The Proliferation of Ad Hoc Procedure, 137 U. PA. L. REv. 2131, 2131-32 (1989). ${ }^{103}$ See Committee on Rules of Practice and Procedure, Judicial ConFerence of the United States, Local Rules Project, app. G-1 (Tent. Draft Nov. 1987). For additional information on the Local Rules Project, see infra notes 108-16 and accompanying text.

104 See 1987 LOCAL RULes REPORT Appendices, supra note 103, app. G-2.

105 See Committee on Rules of Practice and Procedure, Judicial Conference of the United States, Local Rules Project, Preliminary Project REPORT, apps. D-3, D-4, D-5 (Jan. 9, 1987).

${ }_{106}$ See Rules Enabling Act: Hearings Before the Subcomm. on Courts, Civil Liberties and the Administration of Justice of the House Comm. on the Judiciary, 98th Cong., 1st \& 2d Sess. app. 3, at 333-436 (1984) (reprinting the following articles on the subject of local rules: Note, Rule 83 and the Local Federal Rules, 67 Colum. L. Rev. 1251 (1967); Flanders, Local Rules, supra note 95; Flanders, In Praise, supra note 95 ). The examination was in conjunction with looking into judiciary rulemaking generally. 
rules and the Federal Rules. ${ }^{107}$ In the same year, under the auspices of the Committee on Rules of Practice and Procedure of the United States Judicial Conference, the committee's reporter, Dean Daniel R. Coquillette of the Boston College Law School, commenced a massive study of the local rules of the ninety-four federal district courts, starting first with the civil rules. ${ }^{108}$

In July, 1988, the Local Rules Project (the Project) presented its report on local civil rules to the committee. ${ }^{109}$ Its major themes are clear. ${ }^{110}$ The proliferation of local rules exists.

The ninety-four district courts currently have an aggregate of approximately 5,000 local rules, not including many "subrules," standing orders and standard operating procedures. These rules are extraordinarily diverse and their numbers continue to grow rapidly. To give one stark example, the Central District of California, based in Los Angeles, has about thirty-one local rules with 434 "sub-rules," supplemented by approximately 275 standing orders. At the other extreme, the Middle District of Georgia has only one local rule and just one standing order. These local rules literally cover the entire spectrum of federal practice, from attorney admission and discipline, through the various stages of trial, including pleading and filing requirements, pre-trial discovery procedures, and taxation of costs. ${ }^{111}$

${ }^{107}$ See House Comm. ON The Judiciary, Rules Enabling Acr of 1985 , H.R. ReP. No. 422, 99th Cong., 1st Sess. 14-15 (1985).

${ }^{108}$ See Committee on Rules of Practice and Procedure, Judicial ConFerence of the United States, Local Rules Project, pt. I, at 1, 4 (Tent. Draft Dec. 31, 1988) [hereinafter 1988 Local Rules Project]. The Project Director of the Local Rules Project has been Mary P. Squiers, Esq. The consultant to the reporter on the Project has been the author of this paper, Stephen N. Subrin. See id. The district courts mailed their local rules to the Local Rules Project during the period from Spring, 1986 through Fall, 1987; the Project's data were based on the local rules that were received during that period. See id. at 4-5.

${ }^{109}$ See Letter from Daniel R. Coquillette, Reporter, to Members of the Committee on Rules of Practice and Procedure (June 30, 1988), reprinted in 1988 LoCAL Rules Project, supra note 108 (introducing the Report of the Local Rules Project).

${ }_{110}$ The Report was not final as of January 1, 1989, when this article was revised. The major themes and conclusions of the Report did not change.

1111988 Local Rules Project, supra note 108, pt. I, at 1. The Local Rules Project materials that have been sent to each district court, the renumbering of local rules at the request of the Judicial Conference, see infra note 112, and renewed interest in local rules as a result of the recently passed Judicial Improvements and Access to Justice Act, see supra note 63, may well lead to the elimination of a substantial number of local rules. Under the Judicial Improvements Act, "[e]ach judicial council shail periodically review ... [local rules] for consistency with ... [Federal Rules]. Each council may modify or abrogate any such rule found inconsistent in the course of such a review." Judicial Improvements and Access to Justice Act, Pub. L. No. 100-702, 102 
Moreover, the numbering systems of the local rules are extraordinarily diverse, making it difficult to find all of the local rules throughout the country on any one topic. ${ }^{112}$

In order to examine the rules of the various districts in an orderly fashion, and to facilitate a uniform numbering system, the Project divided up the local rules into approximately 103 different topics, and placed them under the various major topics found in the table of contents of the Federal Rules of Givil Procedure, such as "III. Pleadings and Motions," "IV. Parties," and "V. Depositions and Discovery."113 In analyzing 5,032 local provisions that fit within the 103 different topics, the Project found 809 instances of possible repetition with other federal rules or federal law, and 837 instances of possible inconsistency with such law. The Project found 2,288 provisions where local variation was appropriate, and 768 provisions for which model rules could be drafted to accommodate the apparent purposes of those local rules. $^{114}$

The number of local rules provisions that fell within the 103 topics varied not only among the federal courts throughout the country, but also among the federal courts within a single state. ${ }^{115}$ For example, the Northern District of Texas had sixty-five provisions within the topics, while the Western District had twenty-nine. The Eastern District of Virginia had sixty, yet the Western District had seven. ${ }^{116}$

It is instructive to look briefly at one specific subset of local rules. I have chosen discovery because the discovery provisions have turned out to be central to the Federal Rules enterprise, and because the Rules

Stat. 4642, 4651 (1988).

112 See 1988 Local Rules Project, supra note 108, pt. V, at 1 . The Judicial Conference has approved, and urged each district court to adopt, a uniform numbering system. See Report of the Proceedings of the Judicial Conference 103 (Sept. 1988).

113 See 1988 Local Rules Project, supra note 108, pt. I, at 4-5 \& app. A.

114 There were 330 provisions relating to issues that the Local Rules Project suggested should be considered by the advisory committee. These totals were provided to the author by Mary P. Squiers, the Local Rules Project director.

${ }_{116}$ This is a different figure from the number of local rules authorized by a district court. One rule often covered more than one of the Project's topics, and some rules did not fall within any of the topics.

${ }^{116}$ See 1988 Local Rules Project, supra note 108, pt. VIII. This section of the 1988 Local Rules Project provides for each of the ninety-four federal district courts: the number of the local rule analyzed (using the district's own numbering system), the conclusion of the Project as to each rule (should remain subject to local variation; should consider a model local rule on the subject; should be considered by the advisory committee for inclusion in the Federal Rules of Civil Procedure), possible repetition with other federal law, including the Federal Rules, possible inconsistency with other federal law, including the Federal Rules, and a citation to the portion of the 1988 Local Rules Project where the specific topic is discussed and analyzed. 
have accounted for both the most fees and the most controversy. ${ }^{117}$ Discovery rules are also informative with respect to evolving new assumptions concerning American civil procedure.

There are two distinct spirits within the Federal Rules, one old, the other new. Both are exemplified by the discovery rules. The old spirit is expansive and gives broad latitude to lawyers. The liberal discovery provisions were a logical companion to the liberal pleading rules. Permissive discovery would inform the parties of the relevant facts, eliminate surprise, help limit the issues, and provide a basis for either intelligent settlement or an efficient trial. ${ }^{118}$ Broad discovery would also facilitate summary judgment. ${ }^{119}$ The apex of this spirit of extensive attorney latitude was reached in 1970, when the Federal Rule 34 requirement of a motion showing "good cause" for the production of documents and other items was eliminated. ${ }^{120}$ According to the advisory committee notes, this was done in order "to have the rule operate

${ }^{117}$ See, e.g., Discovery, Litigation, Fall 1988, at 7 ("[D]iscovery dominates. The journey from complaint to resolution is a slow trek across the badlands of discovery. The dominance of civil discovery has changed what it means to be a litigator. There are 'litigation associates' who only do document review and interrogatory drafting. Some firms encourage lawyers to specialize, and to spend their entire professional lives only taking depositions. The day is fast approaching-if it is not already here-when litigators will not try cases; they will just discover each other to death. Discovery affects how the public, and clients, see trial lawyers. Few aspects of litigation are more criticized than foot-thick interrogatories and endless depositions. And who can doubt that discovery is a main cause of the escalating cost of lawsuits? The bill for a case not ended quickly will mostly cover discovery."); supra note 100 and accompanying text; see also, Taylor, Judges Identify Causes of Delay in Civil Litigation, LITIGATION News, Dec. 1988, at 3 ("Abuse of the discovery process was identified more often than any other factor as a major cause of delay in civil litigation by both the state and federal judges polled. Approximately $80 \%$ of all of the judges polled said they have had at least some problems with the discovery process. In addition, the overwhelming majority of the 161 federal judges [of 200 interviewed] and 503 state judges [of the 800 interviewed] who said that litigation costs are excessive identified discovery practices as the cause.").

118 See, e.g., Sunderland, Discovery Before Trial Under the New Federal Rules, 15 Tenn. L. Rev. 737, 738-39 (1939) [hereinafter Sunderland, Discovery Under the Federal Rules] (noting the merits of liberal discovery rules); Sunderland, Theory and Practice of Pre-Trial Procedure, 21 J. Am. Judicature Soc'y 125, 126-27 (1937) (discussing the increased efficiency that accompanies pre-trial discovery); Sunderland, Scope and Method of Discovery Before Trial, 42 YALE L.J. 863, 864-65, 869 (1933) [hereinafter Sunderland, Scope and Method] (discussing the limitations of pleadings and the need for discovery to promote efficient resolution of disputes). Edson Sunderland was the member of the initial Federal Rules advisory committee who wrote the initial draft of the discovery provisions.

119 See, e.g., Sunderland, Discovery Under the Federal Rules, supra note 118, at 755-57; Sunderland, Scope and Method, supra note 118, at 872-73 (providing statistics which demonstrated an increase in summary judgments when discovery rules were liberalized).

${ }^{120}$ See FeD. R. Crv. P. 34 \& advisory committee note (1970 amendments). 
extrajudicially."

The amendments of the 1980s brought a second spirit, one of discovery curtailment on a case-by-case basis. The 1980 discovery conference amendment (Rule $26(f)$ ), the 1983 Rule 7 and 11 signature requirements and sanction provisions, the Rule 26(b)(1) amendment permitting discovery limitation by the court on a case-by-case basis, Rule $26(\mathrm{~g})$ certification and sanction provisions, and Rule 16 additions to the purposes of pre-trial conferences all pointed in the new direction: the court should aggressively control discovery as well as other procedural incidents on a case-by-case basis. ${ }^{\mathbf{1 2 2}}$

The Project found approximately 412 local rules provisions dealing with discovery. They divided them into a total of twenty-three separate topics. These included eighteen topics in which the local rules were either repetitive or inconsistent with other federal law, three topics for which the Project thought that either model local rules or local variation was appropriate, and two other topics to be considered by the advisory committee.

The Project found significant differences among the courts with respect to local discovery rules. For example, the Southern District of California had approximately sixteen provisions within the twentythree discovery topics while the Central District had eight, the Northern District, six, and the Eastern District, five. In New York, the Eastern District had approximately twelve discovery provisions that fell within the Project's discovery topics, the Southern District had eight, the Northern District, four, and the Western District, only one. The District Courts for Wyoming and Alaska each had approximately ten discovery provisions falling within the Project's discovery topics, while the Southern District of Iowa had about five and the Western District of Wisconsin, one. ${ }^{123}$

The local discovery rules indicate that many federal judges think that neither attorney latitude nor case-by-case curtailment works well. Leaving the amount of discovery to each individual lawyer acting on

121 FED. R. Giv. P. 34 advisory committee note (1970 amendments).

122 See, e.g., FED. R. Grv. P. 16(a) advisory committee note (1983 amendments) ("The amended rule makes scheduling and case management an express goal of pretrial procedure."); FED. R. Giv. P. 26(b) advisory committee note (1983 amendments) ("The new sentence is intended to encourage judges to be more aggressive in identifying and discouraging discovery overuse."); see also, Shapiro, supra note 10, at 1983-87 (discussing the trend toward increased judicial case management embodied in the 1983 amendment of Rule 16); Subrin, The New Era in American Civil Procedure, 67 A.B.A. J. 1648-51 (1981) (discussing the increased role of the judiciary in monitoring discovery on an ad-hoc basis under the 1983 amendments to Rule 26). Local rules have rejected this case-by-case basis. See infra text accompanying notes 124-31.

${ }^{123}$ See 1988 Local Rules Project, supra note 108, pt. VIII. 
her own or using later motions to reduce the amount of discovery or applying sanctions on abuses has not solved the problem. Moreover, the local rules also suggest that the sheer bulk of discovery documentation has become a burden to the courts: sixty-four district courts have local rules which provide that discovery material need not be filed, although such a non-filing proposal was defeated at the advisory committee in 1980, and Federal Rule 5(d) makes filing the norm. ${ }^{124}$

Fifty-two federal district courts have local rules which require a conference between the parties prior to their bringing any discovery motion. Some of these districts have detailed provisions mandating what must be discussed and recorded. These provisions thus reject the pure adversarial view of discovery. Many federal judges apparently are unwilling to waste time on discovery matters that can reasonably be settled without judicial intervention. ${ }^{125}$ Thirty-three district courts have local rules that outline the form required for discovery motions and accompanying memoranda. This indicates that the judges are seeking a more routinized system to facilitate deciding discovery motions, and perhaps even to discourage them. ${ }^{126}$

Most important, though, are the ways in which federal local rules explicitly limit discovery in advance (although provision is made for additional discovery upon motion). Fifty-four of the ninety-four federal district courts have local rules that limit the number of interrogatories that can be served by each party. These limits range from twenty to fifty interrogatories, with thirty being the most common. All of the limitations "specifically allow the propounding party to serve more interrogatories with leave of court."127 These rules place the burden of proving the necessity of exceeding the limit on the party seeking additional discovery. This contrasts sharply with Federal Rule 26(c), which re-

124 See 1988 Local Rules Project, supra note 108, pt. II, at 91-92; Committee on Rules of Practice and Procedure, Judicial Conference of the United States, Preliminary Draft of Proposed Amendments to the Federal Rules of Civil Procedure, 77 F.R.D. 613, 622-23 (1978) (proposing an amendment to Rule 5(d) to eliminate the filing requirement for discovery materials that are not used in court proceedings); see also 4A G. Wright \& A. Miller, Federal Practice and Procedure $\$ \S 1142$, 1152 (2d ed. 1982) (describing the amendment to Rule 5(d) adopted in 1980 which retained the filing requirement subject to court discretion); FED. R. Crv. P. 5(d) \& advisory committee note (1980 amendments)(same).

${ }^{125}$ See 1988 Local Rules Project, supra note 108, pt. III, at 77-81.

128 See id. at 75-77.

${ }^{127}$ Id., pt. II, at 97-101. For history of the advisory committee's rejection of numeric limits on interrogatories, see, e.g., FED. R. CIV. P. 33 advisory committee note (1946 amendments) (discussing amendment that eliminated original limitation on the number of interrogatories); 8 C. WRIGHT \& A. MilleR, supra note 124, $\S 2168$, at 519-20 (1970) (discussing elimination of numerical limits under 1948 amendment); id. at 222 \& nn.55.5-.7 (Supp. 1988) (discussing rejection of 1978 proposal to limit to 30 the number of interrogatories that could be served by a party). 
quires the party or person who desires to limit discovery to make the motion. ${ }^{128}$

One federal district court has a local rule requiring that each deposition be limited to six hours; another limits the number of depositions to five. ${ }^{129}$ One court has a rule limiting the number of requests for production of documents to thirty; twelve federal district courts limit each of the parties to anywhere from ten to forty requests for admission. ${ }^{130}$ There are several other local rules which impose limitations on the time, place, or form of discovery. ${ }^{\mathbf{1 3 1}}$

The point is not that these local rules are probably inconsistent with the Federal Rules, although this is often true. ${ }^{132}$ Rather, taken as a group, these local discovery rules suggest that a third procedural spirit has evolved: a spirit of absolute curtailment in the absence of proof that persuades a judge that the party seeking more discovery is entitled to it.

The local discovery rules also hint that a fourth spirit is emerging: the fashioning, in advance, of some procedures for particular types of cases. Six federal district courts have local rules which limit initial discovery in class actions to facts pertaining to class certification. ${ }^{133}$ Two courts permit pro se civil rights complainants to engage in Federal Rules discovery "if, and to the extent that, the judge in the exercise of his discretion and for good cause shown grants leave to do so, but not otherwise." ${ }^{134}$ This is not discovery with extensive attorney latitude.

${ }^{128}$ See FED. R. Crv. P. 26(c).

128 See 1988 Local Rules Project, supra note 108, pt. II, at 111.

130 See id. at $112,116$.

131 See id. at 97 (thirteen jurisdictions require court approval of stipulations, including those involving discovery matters); $i d$. at 101 (four jurisdictions require that a deposition to be offered in evidence be abstracted or purged of extraneous and irrelevant discussion between the attorneys); $i d$. at 102 (eight jurisdictions define "reasonable notice" as used in FED. R. Civ. P. 30(b)); id. at 104 (five jurisdictions require that videotaped depositions be transcribed by a reporter simultaneously). There are similar restrictions, also conflicting with the Federal Rules, with respect to depositions for use in foreign proceedings, see $i d$. at 105-06, opening and sealing depositions, see id. at 106-08, telephone depositions, see id. at 110 , stipulating the time and place of depositions, see id. at 111 , and physical and mental examinations of persons, see id. at 11718.

132 In the 1988 Local Rules Project, local rules dealing with requirements of filing, stipulations, interrogatories, use of depositions in court, definition of "reasonable notice," video depositions, depositions for use in foreign proceedings, opening and sealing of depositions, providing the deposition officer with rules, telephone depositions, stipulating the time and place of depositions, limitations on depositions, requests for production of documents, physical and mental examinations, and requests for admissions, are found to be inconsistent with the Federal Rules or other federal law. See 1988 Local Rules Project, supra note 108, pt. II.

${ }^{133}$ See id. at 67-68.

$134 I d$. at 81 . 
Nor is it case-by-case or across-the-board curtailment. Rather, it may be the beginning of a spirit that in a non-trans-substantive manner selects out classes of cases in advance for different discovery treatment from other cases. There are similar non-trans-substantive local rules for other types of cases dealing with topics as diverse as social security, three-judge district courts, black lung, deportation and exclusion, naturalization, and, most frequently, bankruptcy and admiralty. ${ }^{135}$

We may think of this as a spirit of procedural-substantive law integration which seeks in advance to tailor some procedural rules to the unique needs of a particular type of lawsuit. While this approach may have some benefits, it is, of course, the antithesis of trans-substantive uniformity. Moreover, to the extent that this approach is realized by local rules which state courts and other federal district courts do not copy, it reduces intrastate and interdistrict court procedural uniformity.

\section{State Modeling: Who's Following Whom?}

\section{A. Divergence and Uniformity}

Under the Conformity Act, intrastate procedural uniformity was to result from federal judges conforming federal practice to state practice. Depending on whether one looks through the eyes of a Shelton or a Walsh, the conformity was erratic or substantial, and the disruption to lawyers from non-conformity was material or insignificant. ${ }^{136}$ To those who advocated federal rules, intrastate uniformity was to result from the modeling by state supreme courts of state procedure on federal. The federal rules were to be an enlightened magnet. ${ }^{137}$ Again, depending on one's point of view, the modeling was substantial or insubstantial.

In 1940, Arizona became the first state to change its civil procedure to follow the federal model. ${ }^{138}$ Norman Hull, at the time a Phoe-

135 See id. at 34-37 (social security cases); id. at 37-40 (three judge district courts); $i d$. at 49-51 (black lung cases); id. at 86-88 (deportation and exclusion cases); id. at 170-71 (naturalization); id., § 3 (Suggested Local Rules), at 45-48 (social security cases); $i d$. at $48-52$ (three judge district courts); $i d$. at 128-29 (naturalization petitions). Most, if not all, jurisdictions have local rules specifically addressing bankruptcy, and approximately 30 have local rules for admiralty cases. The Knox Committee Report thought it was "clear and logical" to have separate sets of local rules adopted to civil, admiralty, bankruptcy, and criminal cases. See KNOX CoMmitreE REPORT, supra note 84 , at 20 . Of course, the Federal Rules also have some non-trans-substantive provisions, such as Rules 9(b), 9(h), 14(c), 23, 23.1, and 71A.

${ }_{136}$ See supra text accompanying notes 16-21 \& 43-45.

137 See supra text accompanying note 39.

${ }^{138}$ See Oakley \& Coon, The Federal Rules in State Courts: A Survey of State Court Systems of Civil Procedure, 61 Wash. L. REv. 1367, 1381 (1986). 
nix lawyer, argued in favor of Arizona's adoption of the Federal Rules. Hull believed that adoption of the Federal Rules was advisable for three reasons. First, the United States Supreme Court had examined the Rules at length and believed them to be highly desirable. Second, they were the product of thousands of lawyers, and Arizona was unlikely to improve upon them. Third, "lawyers practicing before the state courts would be governed by the same rules and, when practicing before any federal court in the United States they could walk into the courtroom and feel at home."139

The extent to which the Supreme Court actually had studied the Rules before their adoption was a matter of dispute between Charles E. Clark, who argued that the Supreme Court played an important role, and his more skeptical colleague, James William Moore. ${ }^{140}$ Although many lawyers and judges did offer suggestions to the advisory committee, the final product primarily reflected the views of Clark and Edson Sunderland, a University of Michigan Law School professor. ${ }^{141}$

Nonetheless, Hull's reasons were similar to the arguments of modeling proponents both before and after the Enabling Act was passed. ${ }^{\mathbf{1 4 2}}$ John Frank, a member of the symposium panel, was at Yale Law School as a student and a faculty member before becoming a lawyer in Arizona. ${ }^{143}$ He was one of several lawyers and law professors, many of whom had studied or taught at prestigious Eastern law schools, who enthusiastically embraced the Federal Rules. ${ }^{144}$ Frank explained in

139 Allen, The New Rules in Arizona, 16 F.R.D. 183, 184 (1954).

140 Compare J. Moore, Federal Practice $\S \S 0.511-0.512$ (1st ed. 1959) (noting the Supreme Court can only devote a minimal amount of time and energy to rulemaking) with Clark, The Federal Rules of Civil Procedure: 1938-1958: Two Decades of the Federal Civil Rules, 58 Colum. L. REv. 435, 441-42 (1958) (discussing the active supervisory role played by the Supreme Court) and Clark, The Role of the Supreme Court in Federal Rule-Making, $46 \mathrm{~J}$. AM. Judicature Soc'y 250, 251-52 (1963) (same).

${ }_{141}$ See Subrin, supra note 1, at 961-73 (on Clark); id. at 967 (on Sunderland). Correspondence to the advisory committee shows that Clark was responsible for drafting the majority of the provisions, while others were initially drafted by Sunderland. See Letter from Edgar B. Tolman to the United States Supreme Court Advisory Committee On Rules For Civil Procedure (Oct. 18, 1935).

${ }^{142}$ For one of the modeling arguments before the Enabling Act was passed, see supra note 39 and accompanying text.

143 See Who's Who In America 1028 (45th ed. 1988).

144 Moore pointed out that "in numbers the East may have been overly represented." J. MOORE, supra note 140 , at $\S 0.511$. There was (and is) a certain inbred quality of many of those most associated with the Federal Rules and modern American civil procedure. James William Moore was an instructor of law at Yale in 1935, and became a professor at Yale Law School in 1943. He was the original author of Moore's Federal Practice. See Who's Who IN AMERICA, supra note 143, at 1978 (44th ed. 1986). Fleming James, Jr. was a student at Yale, and later a law professor there. See id. at 1583 (39th ed. 1976). Moore and James were assistants to Clark (then Dean at 
1967 why Arizona would rather be uniform than right: "We would prefer to have not even a day in which the Arizona lawyer is practicing under different systems in the two courts ... ."145 Frank added to Hull's reasons: Arizona lawyers and judges had become accustomed to the Federal Rules and could rely on federal procedural precedents and treatises, and the Rules were usually good ones. ${ }^{146}$

Within a decade, a few other Southwestern and Western states with relatively small populations followed Arizona's lead. Colorado (1941), New Mexico (1942), and Utah (1950) adopted the Federal Rules, but during this initial period these four states stood alone. ${ }^{\mathbf{1 4 7}}$ Nebraska, which like Arizona was an early code state without a large population, might have been expected to follow, but Nebraska has never adopted the Federal Rules. ${ }^{148}$ The debate there over modeling took place during the 1940s and produced anti-uniformity arguments, which, like the Arizona pro-modeling position, still make sense.

In 1942, H.W. Shackelford of the Nebraska Bar wrote one of the few articles that clearly articulates the anti-modeling position. ${ }^{149}$ Shack-

Yale Law School) during the drafting process. Sunderland was a research associate at Yale Law School from 1931-1933, during Clark's deanship. See id. at 2684 (26th ed. 1950). Charles Alan Wright graduated from Yale Law School in 1949, and then became Clark's law clerk when Clark was a Judge of the United States Court of Appeals for the Second Circuit. See id. at 3371 (45th ed. 1988). Geoffrey Hazard, Jr. has been a professor at Yale Law School since 1971. See id. at 1359. He and James have authored a major treatise on Civil Procedure. See G. Hazard \& F. James, Crvil ProCEDURE (3d ed. 1985). Alexander Holtzoff (later United States District Judge for the District of Columbia) was a Special Assistant to Attorney General Homer Cummings (who was instrumental in having the Enabling Act passed) and participated in the drafting process, on assignment from the Attorney General's office. See WHO's WHO IN AMERICA, supra note 143, at 1067 (36th ed. 1970). Holtzoff was an initial author of J. Barron \& A. Holtzoff, Federal Practice and Procedure (1951); Wright revised the treatise, which later became Wright $\mathcal{E}$ Miller. Benjamin Kaplan, Albert Sacks, and Arthur Miller were all professors at Harvard Law School who succeeded Clark as reporters to the advisory committee. See WHO's WHO IN AMERICA, supra note 143, at 1626 (45th ed. 1988) (Kaplan); id. at 2696 (Sacks); id. at 2149 (Miller). The current Reporter, Paul Carrington, is a graduate of Harvard Law School, where he was also a teaching fellow. See id. at 497. Both Cummings and William DeWitt Mitchell, the first chairman of the advisory committee, were students at Yale Sheffield Scientific School, and Cummings received his law degree at Yale. See id. at 595 (29th ed. 1956) (Cummings); id. at 1799 (Mitchell); see also, Subrin, supra note 1, at 971 n.369 ("In terms of education, type and size of law firm, clients, offices held in professional organizations, and membership in social clubs, the Advisory Committee members, particularly the lawyers, appear to comprise an extremely elite group.").

${ }_{145}$ Frank, Arizona and the Federal Rules, 41 F.R.D. 79, 85 (1967).

146 See id. at 87-88.

147 See Oakley \& Coon, supra note 138, at 1428 app. The District of Columbia also became a "replica state" in 1942. See id. For the meaning of "replica state," see infra note 153 and accompanying text.

148 See Oakley \& Coon, supra note 138, at 1407.

149 See Shackelford, Why Adopt New Rules of Pleading and Practice?, 21 NEB. L. REv. 94 (1942). 
elford asserted that Nebraska's code procedure was one of the simplest and most workable in the country, that the cost of operating under it was not unduly burdensome, and that the Federal Rules were designed for the larger, more complicated cases that make up federal practice. "The more simple 'two-party' controversies that form the mill run of cases brought in our state courts do not require elaborate and technical rules of procedure, such as are embodied in the proposed rules." $150 \mathrm{He}$ did not find that the Federal Rules simplified procedure, as the proponents claimed, nor did he see a need to give the trial judge greater control over litigation. He noted, with some humor, that although the Federal Rules had been "extensively propagandized" by publishers of law books, only four or five of the forty-eight states had adopted them; it seemed too early to predict that they would be universally adopted. ${ }^{151}$

Shackelford was correct to question universal adoption. A 1982 article by Professor John Oakley of the University of California, and his former student, Arthur Coon, provides a comprehensive survey of state modeling. ${ }^{152}$ They used a refined, nine variable test to determine what they call a "replica" state. ${ }^{153}$ They report that in 1975 Massachusetts became the last of twenty-two states plus the District of Columbia to conform its procedure substantially to the Federal Rules through judicially promulgated rules; if one includes statutorily adopted versions of the Federal Rules, there are four additional states, making a total of twenty-six. ${ }^{154}$

For the most part the replica states are those with the smallest populations. Of the ten most populous states, only Ohio is a replica state. ${ }^{155}$ The other nine-Galifornia, New York, Texas, Pennsylvania, Illinois, Florida, Michigan, New Jersey, and North Carolina-have not adopted the Federal Rules either judicially or legislatively. ${ }^{156}$ In

180 Id. at 99.

161 Id.

152 See Oakley \& Coon, supra note 138.

${ }^{163}$ Oakley \& Coon, supra note 138 , at $1372-75$. Their nine criteria are: judicially promulgated rules; conformity with the Federal Rules of Civil Procedure organization and numbering; merger of law and equity; conformity with federal joinder rules, as amended in 1966; conformity with federal discovery rules, as amended in 1970; summary judgment modeled on the Federal Rules; adoption of "notice pleading"; if the state rules are "idiosyncratic . . . by federal standards" they must still be consistent with "the Federal Rules' philosophy of 'procedure as the handmaiden of justice" "; if Federal Rules precedents and commentary are persuasive authority. Id. at 1374-75.

164 See id. at 1425, 1428 app. Oakley and Coon found that Georgia, Kansas, Oklahoma, and North Carolina "operate under statutorily adopted versions of the Federal Rules." Id. at 1378.

155 See id. at 1429 app.

${ }^{168}$ See id. 
contrast, eleven of the fifteen least populous states are replica states. ${ }^{157}$ As of 1982 , only $26 \%$ of the United States population was governed by a procedural system that replicated the Federal Rules. ${ }^{158}$ Oakley and Coon found that even "when a looser test than replication was applied to classify states as generally following the model of the Federal Rules, the resulting tally embraced a majority of states but a minority of our national population."159

On the other hand, of the non-replica states, eleven have notice pleading-a hallmark of the Federal Rules. ${ }^{160}$ Seven of those, plus another three states, have procedural systems very similar to the Federal Rules, notwithstanding some important variations. ${ }^{161}$ That makes thirty-two states that are either replica states, or which by legislation or court rule have adopted major portions of the Federal Rules. Even by this method, though, eight of the ten most populous states would not be counted as having adopted the Federal Rules. ${ }^{162}$

The major national promoters of state-modeling insisted that partial adoption of the Federal Rules by a state was worse than non-adoption. ${ }^{188}$ By that test, there was substantial non-adoption. But a visitor to this country from another legal system would probably conclude that there was a good deal of intrastate and interstate uniformity. The most important attributes of the Federal Rules-merger of law and equity, ease of pleading and amendment, liberal joinder of parties and theories, broad discovery, and summary judgment-would probably be part of the rules of most civil litigation whether in a federal or state court. ${ }^{164}$

${ }^{157}$ See id.

158 See id. at 1425 n.394, 1428 app. (Oakley and Coon use a total population figure of $226,549,000$, and their replica states, including the District of Columbia, have a population of $59,890,000$ ).

169 Id. at 1369.

260 See id. at 1428 app.

${ }_{181}$ See id. at 1377-78. These states are Idaho, Mississippi, Nevada, Georgia, Kansas, Oklahoma, North Carolina, Arkansas, Delaware, and South Carolina.

182 See id. at 1377-78, 1429 app. The two states that would be included are Ohio (replica state) and North Carolina (notice pleading/federal code procedural system). In a separate article, a former student of mine, Steve Halpern, and I are exploring the historical context of modeling on a state by state basis, and the phenomenon of large state rejection of the Federal Rules.

${ }_{103}$ See, e.g., Clark, The Texas and the Federal Rules of Civil Procedure, 20 TEx. L. REv. 4, 14 (1941) ("I have stated my view that piecemeal reform may often be less desirable than no reform at all. For it may serve to upset the bench and bar by the need of learning a new system which is little advance and thus prejudice the securing of complete reform for many years."); Clark, Dissatisfaction with Piecemeal Reform, 24 J. AM. Judicature Soc'y 121, 121 (1940) (slight gain from piecemeal reform "is not worth the cost of the confusion entailed, and . . the more adequate reform is actually delayed by the half-way steps").

${ }_{184}$ See McKusick, State Courts' Interest in Federal Rulemaking: A Proposal for Recognition, 36 ME. L. Rev. 253, 253 (1984) ("Even those states such as Illinois, 
Uniformity, however, was advocated not primarily to promote a national procedural philosophy, but rather to permit the identical procedural rules in both state and federal courts in order to make it easier to practice in both. In large measure, this goal has not been met. ${ }^{165}$

\section{B. Emerging Patterns}

The road to uniformity has never been a one-way street. Whether in terms of specific procedural rules or broad procedural outlook, the states have perhaps given as much as they have taken. Connor Hall may prove to be partially correct: before the tale has ended, portions of federal court procedure may evolve to a new conformity to state law.

Discovery again provides an interesting focal point. In 1932, George Ragland's Discovery Before Trial documented a rich variety of state pre-trial discovery techniques. ${ }^{168}$ Sunderland, who drafted the Federal Rule discovery provisions, ${ }^{167}$ acknowledges his debt to the prior discovery experience in the states. ${ }^{168}$ Sunderland's approach was inclusion, not exclusion. He took the types of discovery that were available in some state trial courts, and made them available to all parties and in all cases, subject to protective orders and sanctions. ${ }^{\mathbf{1 6 9}}$

Looking to patterns in discovery subsequent to the promulgation of the Federal Rules, I stress the Massachusetts experience. This is only because I know much more about it than about the developments in other states. ${ }^{170}$ Our local rules, standing orders, and legal culture may

Michigan, New York, and Pennsylvania that have not modeled their civil procedure generally on the federal rules have nonetheless adopted comparable provisions to govern certain matters as, for example, joinder of parties, class actions, or discovery. Thus, the Federal Rules of Civil Procedure have come to serve the same function that is served in other fields of the law by the work product of the National Conference of Commissioners on Uniform State Laws. The federal civil rules are de facto model rules for state rulemakers." (footnotes omitted)); Weinstein, After Fifty Years of Federal Rules of Civil Procedure: Are the Barriers to Justice Being Raised?, 137 U. PA. L. REv. 1901, 1901-02 (1989) (extolling the influence of the Federal Rules).

168 This non-uniformity is due not only to a failure of state adoption of the Federal Rules. Both federal local rules, see supra notes $98-135$ and accompanying text, and state local rules, see infra notes 199-201 and accompanying text, contribute to the nonuniformity.

166 See G. Ragland, Discovery Before Trial 19-266 (1932). Federal local rules also often look to state procedure. See Flanders, Local Rules, supra note 95 at 234-235 (citing study showing voir dire practice in federal court often follows state practice).

167 See supra note 118.

${ }^{188}$ See Sunderland, The New Federal Rules, 45 W. VA. L.Q. 5, 21-22 (1938); Proceedings, supra note 98, at 254.

169 See Sunderland, supra note 168, at 21-22.

170 I studied law in Massachusetts and practiced law there for almost eight years (primarily as a trial lawyer in civil cases). Currently, I teach there and have been Reporter to the Massachusetts Supreme Judicial Court Standing Advisory Committee 
well be unrepresentative; the problems we have addressed, however, and some of our approaches are not. ${ }^{171}$

During the period that Arizona was adopting new procedure based on the Federal Rules, the Massachusetts Legislature refused to recognize the authority of the Massachusetts Supreme Judicial Court to regulate practice and procedure. ${ }^{172}$ Massachusetts ultimately arrived at the Federal Rules through two steps. First, in 1966, after a lengthy lobbying effort by Chief Justice G. Joseph Tauro of the Massachusetts Superior Court and the bar associations, the Supreme Judicial Court promulgated a rule for oral depositions and other types of discovery patterned on the Federal Rules. Massachusetts was the forty-second jurisdiction to authorize oral depositions. ${ }^{173}$

Tauro wrote:

I personally contacted many lawyers and judges from jurisdictions having broad oral discovery rules and thoroughly discussed their actual experience with the rules. The vast majority [said] oral discovery saves lawyers', litigants' and courts' time and effort since it promotes more realistic settlement negotiations, brings lawyers together at an early stage thus facilitating early settlement negotiations and makes shorter and more orderly trials possible. ${ }^{174}$

In order to dispel the fears of the Massachusetts plaintiffs' bar, he reported, based on the results of a questionnaire he mailed to plaintiffs' lawyers in Pennsylvania and New Jersey, that harassment through oral depositions was not a significant problem. ${ }^{175}$

In 1968, the Massachusetts Judicial Council began a procedure that ultimately resulted in the adoption of the bulk of the Federal Rules

on the Rules of Civil Procedure since 1982.

${ }^{171}$ For instance, the Massachusetts limitation of thirty interrogatories has become the norm in federal courts, see supra note 127 and accompanying text, and tracking was proposed for federal courts prior to its adoption in Massachusetts, see infra notes 204-07 and accompanying text.

172 See Grinnell, Regulation of Practice and Procedure in Massachusetts, Mass. L.Q., Jan.-Apr. 1938, at 9, 10; The Rule-Making Bill, MAss. L.Q., Apr.-June 1939, at 8, 8-15; Fifteenth Report of the Judicial Council of Massachusetts, MAss. L.Q., Jan.-Mar. 1940, at 5, 10-11.

${ }^{173}$ See Tauro, Oral Discovery-A Brief Recapitulation, 50 Mass. L.Q. 215, 224 (1965) [hereinafter Tauro, Oral Discovery]. Shortly thereafter the Massachusetts Supreme Judicial Court adopted Rule 15, introducing oral depositions to the Commonwealth. See Tauro, Report to the Members of the Bar-IV, 51 Mass. L.Q. 345, 346 (1966); see also, Facher, Supreme Judicial Court Rule 15-Landmark in Massachusetts Procedure, 51 Mass. L.Q. 5, 5-50 (1966) (describing and discussing the operation, application, and effects of Rule 15).

174 Tauro, Oral Discovery, supra note 173, at 216.

175 See id. at 218-24. 
in 1974 (albeit with some variations to comport with Massachusetts practice). ${ }^{176}$

There had been an earlier attempt to have the Federal discovery rules adopted for Massachusetts. I mention this episode because Massachusetts too had a gentleman who had intense doubts about aspects of the Federal Rules enterprise. George P. Dike was a Boston lawyer who had been a litigator since 1903. ${ }^{177}$ For ten years he had tried cases in federal court under the old equity rules, for twenty-five years under the Equity Rules of 1912, and for thirteen years under the Federal Rules of Civil Procedure. ${ }^{178}$ In 1951, thirteen years after the Federal Rules became law, Dike concluded that " $[t]$ he preliminary proceedings have grown until the whistle is bigger than the boiler."179

Dike explained what a great gain it had been when the federal courts, as a result of the Equity Rules of 1912, gave up trial by written deposition.

The other day I picked up an old record and found that testimony by deposition was taken on forty-four days between January 19, 1898 and April 28, 1900, a period of two years and three months. I shudder when I recollect the total injustice of the procedure. The expense was enormous and delays terrific. ${ }^{180}$

Dike was critical of the Federal Rules:

Now . . . we have this mongrel procedure which is neither trial by deposition nor trial in open court. . . . [B]oth parties file interrogatories and requests for admissions often running to many pages and requiring an enormous amount of research to answer. Next each side proceeds to examine in $a$ lawyer's office "any person" including opposing parties, officers and directors on any subject germane or not germane to the case. This is a licensed fishing expedition-a wearisome exasperating performance for reluctant witnesses and for counsel alike. There is constant abuse of the privilege of

${ }^{176}$ See A Symposium: The Massachusetts Rules of Civil and Appellate Procedure, 59 MAss. L.Q. 113, 115-26 (1974); Project to Revise Massachusetts Rules of Procedure Begins, 53 Mass. L.Q. 337, 337 (1968).

${ }_{177}$ See Dike, Comments on the Federal Rules For Discovery: A Criticism of Trial by Deposition, MAss. L.Q., Oct. 1951, at 15, 15-16 (speech delivered at the Annual Meeting of the American Bar Association, at a symposium on the Federal Rules of Civil Procedure sponsored by the Section of Judicial Administration).

${ }^{178}$ See id. at 15.

179 Id. at 16.

180 Id. at 17 . 
discovery. The result may be hundreds or even thousands of pages of transcript, often taken up with the wrangling of counsel and containing' a minimum of information material to the issues of the case. These depositions are even worse than those taken under the original equity rules because Rule 26(b) expressly sanctions examination as to wholly inadmissible matters. ${ }^{181}$

Dike said that he had heard that the drafters of the Rules thought that discovery abuse could be controlled by the courts, but he felt that busy judges showed "an obvious distaste" for ruling on discovery motions, which could frequently be heard only after "considerable delay." Consequently, lawyers were encouraged to engage in "some pretty wide deviations from the line of proper interrogation."182 The solutions, he thought, might be to limit discovery to written interrogatories, unless the court gave specific approval for depositions and limited in advance the permissible "range of the examination."183

Our whole preliminary procedure must be simplified and shortened.

But whatever the remedy we must not revert to trial by deposition. We must not give up the great gain which was made when we adopted the Equity Rules of 1912, and we must eliminate the waste, delay and injustice of the present procedure preliminary to trial. ${ }^{184}$

Both state and federal courts have tried to find ways to limit discovery without resorting to ongoing day-by-day judicial case management. Although Dike failed to prevent the adoption of the Federal discovery provisions, Massachusetts did not totally replicate the federal model, retaining the thirty interrogatory limit which had been previously mandated by statute. ${ }^{185}$ Furthermore, in an instance of reverse modeling, the Massachusetts Federal District Court has recently adopted the state limitation by local rule. ${ }^{186}$

An April 1988 editorial in the Massachusetts Lawyers Weekly urges further movement in the direction of pre-defined limitations (the

${ }^{181}$ Id. at $18-19$.

182 Id. at 19.

${ }^{183} I d$. at 21 .

184 Id.

185 See Mass. R. CIv. P. 33. The thirty interrogatory limit originated from Mass. AnN. Laws ch. 231, \& 61 (Law. Co-op. 1986).

${ }^{188}$ See D. Mass. Local R. 16(a)(1). 
third spirit of federal procedure), and different rules for different categories of cases (perhaps the fourth spirit of federal procedure) as well:

There are no simple remedies. The overburdened court system could hardly tolerate the geometric increase in court time that would be required to supervise depositions on a case-by-case basis. There are, however, several alternatives worthy of consideration.

Much abuse could be curbed by a rule that restricts unbridled depositions but that leaves the door open for greater use of depositions in complex cases through special application to the court. One can contemplate a rule restricting the number of persons who may be deposed and the duration of each deposition ..... An exception could be allowed if all parties consent, thereby exempting complex cases where all parties must depend on extensive discovery. The court could also expand the number of depositions, their duration and any geographic limitations for "special cause."187

The trend to numerical limitations on interrogatories was already evident by 1981, when the Texas Supreme Court ordered that, without agreement or leave of court, there could only be two sets of interrogatories, each having a number of questions including subdivisions "so as not to require more than thirty answers." 188 The committee members were most concerned about the effects of lengthy interrogatories in small cases: "Glearly the drafters intended the rule to protect the small claimant from being priced out of the litigation market by an overinterrogating adversary."189 At least one Texan evidently suggested the impracticality of establishing a single limit for all cases. ${ }^{190}$ "Practically, it seems ludicrous to impose the same limit on a complex antitrust case as on a $\$ 300$ tort claim."191 By 1981, "at least eleven other states and twenty-seven federal district courts had adopted their own limits on interrogatories." ${ }^{182}$ As we have seen, at least fifty-four of the ninety-four federal district courts now also have such limitations. ${ }^{193}$

Many states have been reluctant to try to deal with discovery

${ }^{187}$ Depositions Abuse, Mass. LAw. Weekly, Apr. 4, 1988, at 6.

188 Tex. R. Giv. P. 168(5).

189 Note, Coping with the Jekyll-Hyde Nature of Interrogatories by Imposing a Numerical Limitation: The Uses and Abuses of Discovery Procedures as Exemplified by Texas Rule of Civil Procedure 168, 2 Rev. Litigation 95, 102 (1981).

180 See id. at 106.

191 Id.

182 Id. at 95 n.3.

193 See supra note 127 and accompanying text. 
abuse by ad hoc, case-by-case judicial determinations. On June 13, 1983, attorney John M. Mullen of Boston, long a modeling advocate, wrote to the Chief Justice of the Massachusetts Supreme Judicial Court urging the adoption of new federal amendments designed to curtail discovery abuse: ${ }^{\text {194 }}$

With vast resources in time and funding available to them, national bar associations, law schools, scholars and federal authorities have the federal procedural rules under constant study and review. It makes elementary common sense for Massachusetts, with limited resources, to conform its procedural rules, as near as may be, to the federal rules as they are from time to time amended in the light of study and experience . . . . It does not make sense to have the strength of that policy dissipated by delegation of its implementation to persons who may be interested in attention-seeking innovations or self-serving obstructiveness. ${ }^{195}$

The Massachusetts Standing Advisory Committee of Civil Procedure Rules, after lengthy discussions of the 1980 and 1983 federal amendments relating to discovery and other matters, has been content to "wait and see" before recommending their adoption:

[T]he federal amendments are tailored to a federal system, which, unlike Massachusetts, relies on assigned rather than circuit judges, and on the availability of magistrates. There is also a strong feeling among the members of the Committee that if discovery abuse does exist, there are already a number of provisions under the present rules to control that abuse, although such provisions do seem to be underutilized. There is also concern . . . that each time a new procedural device is added to the system . . . it provides more opportunity to expand the number of satellite procedural controversies, to harass the opposition, and to increase expenses and fees. New procedural steps would also reduce the already scarce time available to Massachusetts judges to preside over trials in open court. ${ }^{196}$

104 Letter from John M. Mullen to Hon. Edward F. Hennessey, Chief Justice, Massachusetts Supreme Judicial Court (June 13, 1983). The new federal amendments to the discovery rules were to become effective in August 1983.

185 Id. at 1.

106 Memorandum from Standing Advisory Committee on Rules of Civil Procedure to Massachusetts Supreme Judicial Court 2-3 (Dec. 9, 1983). The memorandum also states:

We are not of the opinion that there should be automatic uniformity with 
Massachusetts is by no means the only replica state to withhold its adoption of the new federal amendments. Since 1980, Federal Rule 26 has been amended in three major ways, each one designed to curtail discovery abuse on a case-by-case basis. ${ }^{197}$ These amendments represent the second procedural spirit under the Rules. Only eight of the twentytwo states in the United States that were considered replica states by the Oakley and Coon survey have adopted all three Rule 26 amendments. Eleven have adopted none of them. Fourteen out of twenty-two have adopted the new Rule 11. At this point, there may be only eight or so current replica states: Minnesota, Montana, North Dakota, Tennessee, Utah, Vermont, Washington, and West Virginia. Ohio, the most populous replica state, has adopted none of the new rules. Thus, very little of the population is covered by up-to-date Federal Rules in state court. 198

Further complicating things, the federal local rule phenomenon has been duplicated by the states. For example, the Federal District Court of Arizona has local rules covering approximately fifty-eight of the Project's topics. ${ }^{199}$ The Uniform Rules of Practice of the Superior Court of Arizona cover eighteen main topics and about forty-five subtopics. ${ }^{200}$ But Maricopa County has about thirty pages of "local local" superior court rules, including rules for different judicial districts: "local, local, local" rules perhaps. Over one hundred different "local local" rules in Maricopa County relate to all cases and civil cases; they cover many of the same matters that the Project found to be covered at the federal level. ${ }^{201}$ Thus, it is unlikely that a lawyer familiar with Arizona

Federal Rules and do not believe in uniformity merely for the sake of uniformity. We would not recommend significant changes to the Massachusetts Rules of Civil Procedure as they presently exist unless dictated by reason and experience, and unless such changes would be compatible with our state court system.

Id. at 3 .

197 See supra note 122 and accompanying text.

198 One might argue that those replica states that had adopted two or more of the three discovery amendments and the new Rule 11 provisions have remained in the "replica" camp; this would add Arizona and Wyoming. If each of the replica states and the District of Columbia had adopted all five of the Rule 26 amendments and the Rule 11 amendments, that would be 92 amendments. They in fact have adopted 46 , or $50 \%$. The state adoptions were checked as of December 31, 1988, except where 1989 amendments had reached Boston libraries.

189 See 1988 Local Rules Project, supra note 108, pt. VIII.

200 See UNIF. R. Practice Super. CT. ARIz. (including amendments received through August 15, 1988).

201 See Local R. Practice Super. Cr. Maricopa County (including amendments received through August 15, 1988). Rule 9 (with its several sub-divisions) gives rules for the Northeast Judicial District. Rule 10 (with its several sub-divisions) gives rules for the Southeast Judicial District. See id. 
federal procedure would automatically feel procedurally comfortable in an Arizona state court or a different federal district court, although all three systems purport to be governed by the Federal Rules of Civil Procedure or rules patterned on them. ${ }^{202}$ Moreover, this statement does not consider the standing orders or standing operating procedures of individual judges, assuming one can find them!

There are other state developments which have the potential to destabilize modeling and which relate to the emerging spirits of American civil procedure: time standards for the disposition of cases and predefined tracking systems. ${ }^{203}$

On April 7, 1986, the Massachusetts Supreme Judicial Court ordered that civil cases with the exception of family law cases be disposed of "within 24 months after filing." "204 The order noted the need to attack the "excessive delay and excessive cost" of litigation. ${ }^{205}$ Former Chief Justice Edward F. Hennessey explained that:

To succeed, time standards require a substantial change in the so-called 'local legal culture,'. . . the customary practices and expectations of both trial lawyers and judges. Unfortunately, the 'local legal culture' in Massachusetts . . . is predicated on the likelihood, if not the inevitability, of delay in the trial of civil cases. This, in turn, is largely a product of a chronic shortage of judges ....

To reverse these ingrained expectations, the courts, in fairness to all litigants, must consistently enforce the time standards implementation programs, especially with respect to discovery proceedings . . . .

To implement the time standards, the Administrative Justice of the Superior Court (the highest trial court) issued a "Standing Order." All cases are assigned to one of three presumptive track schedules: Fast ("F"); Average ("A"); and Accelerated ("X"). Track assignments de-

202 Although the commentaries of John Frank and Janet Napolitano, both Phoenix lawyers, confirm the impression of local rule proliferation in Arizona, Ms. Napolitano describes the work of the Arizona local rule sub-committee in trying to ameliorate the problem. See Napolitano, Comment on Federal Rules, Local Rules, and State Rules: Uniformity, Divergence, and Emerging Procedural Patterns, 137 U. PA. L. REv. 2063, 2063-65 (1989).

${ }^{203}$ The recent Massachusetts experience in these two areas reflects three different spirits: case-by-case management, absolute curtailment, and non-trans-substantive civil procedure. See infra notes 204-09 and accompanying text.

${ }^{204}$ Order of the Massachusetts Supreme Judicial Court (Apr. 7, 1986).

205 Id. (1988).

${ }^{208}$ Hennessey, Twelfth Annual Report to the Bar, 73 Mass. L. REv. 3, 11 
pend on the nature of the case, although the parties may, for "good cause" shown, request that a case be designated to a different track. ${ }^{207}$

The fast track covers certain contract cases and negligence torts; the average track covers other torts and complicated equitable remedy cases; the accelerated track covers appeals from administrative agencies, labor disputes, abuse petitions, mortgage foreclosures, and other miscellaneous cases. There are forty-six categories of cases divided up among the three tracks.

Each track has its own calendar designating the time by which procedural steps must be completed. For instance, the fast track requires that discovery requests be filed and depositions completed within ten months of filing, a pre-trial conference be held within twelve months, and a firm trial date set within the next two months. Thus, trials are supposed to start within fourteen months of filing. The average track cuts off discovery at sixteen months, and requires a firm trial date within twenty-four months. The accelerated track requires a hearing or trial within six months of filing. There is an exception for complex cases that require additional time. ${ }^{208}$

Tracking dramatically affects discovery without directly amending the discovery procedural rules. Like the numerical limitations on interrogatories, it embraces the third procedural spirit-specific limits. Tracking also departs from trans-substantive procedure. It specifically singles out different categories of cases for different treatment, sug-

${ }^{207}$ The case is initially assigned to a track dependent on the nature of the action as designated by the plaintiff on the civil action cover sheet. See Standing Order No. 188, Applicable to All Counties, Subject: Time Standards, Commonwealth of Mass., Sup. Ct. Dept., at 3 (Feb. 1, 1988) (Thomas R. Morse, Jr.) [hereinafter Standing Order No. 1-88]. California has experimented with tracking cases in which the claim does not exceed $\$ 25,000$, by providing for reduced and simpler pleadings, motions, discovery, and trials. See Epstein, Reducing Litigation Costs for Small Cases, JUDGE's J., Spring 1981, at 9, 10; McDermott, Equal Justice at Reduced Rates, JuDGE's J., Spring 1981, at 16, 17-18. For similar experiments in Kentucky and Colorado, see Chapper, Limiting Discovery, JuDGE's J., Spring 1981, at 20, 23. There have also been experiments with "fast track" cases at some appellate courts. See Chapper, Fast, Faster, Fastest, JUDGE's J., Spring 1981, at 50, 52-56. A similar suggestion has been made for tracking at the federal level. See McMillan \& Siegel, Creating A Fast-Track Alternative Under the Federal Rules of Civil Procedure, 60 NOTRE DAME L. REv. 431, 431 (1985); see also Best, Opening Statement -Where Do We Go From Here?, Litigation, Fall 1988, at 1, 2 (stressing the importance of solving the problem of overcrowded dockets and proposing study of the fast track concept); Holzberg, Section Leadership Debates New "Fast-Track" Civil Rules, Litigation News, Apr. 1988, at 3, 3 (reporting that McMillan \& Siegel's proposals to amend the Federal Rules of Civil Procedure to create a fast track for certain civil cases received mixed reviews from a joint meeting of the Litigation Section Council and Committee Chairpersons of the American Bar Association).

${ }^{208}$ See Standing Order No. 1-88, supra note 207, at 5 ("[T] by their very nature require special tracking standards."). 
gesting the fourth spirit of American civil procedure: tailoring procedural rules in advance for specific types of cases. ${ }^{209}$

Arizona has a uniform set of interrogatories available for automobile accident cases. ${ }^{210}$ California has also experimented with uniform sets of interrogatories for a variety of types of cases. ${ }^{211}$ Other states have turned to workers compensation schemes, administrative agencies and specialized courts, automobile lemon laws, consumer protection statutes, and malpractice panels-to name a few examples - in an attempt to better mesh process and substance. ${ }^{212}$ Without court rule or statutory provision, some federal courts have required more specificity in pleading in certain types of cases, such as anti-trust and civil rights. ${ }^{213}$

Most commentators now agree that discovery abuse is not primarily a general problem, but rather is prevalent in a relatively small number of complex cases in which the stakes are high enough to justify high fees. ${ }^{214}$ It also appears that there may be roughly two types of liti-

200 The order also includes aspects of the second spirit: case-by-case management.

Nothing in this Order shall act as a bar to any form of early court intervention for purposes of screening cases for remand, conciliation, case evaluation or reference to a master. No later than six months from entry date, all cases should be examined and appropriate orders may be entered notwithstanding the previously assigned presumptive track schedule.

Id. at 2 .

${ }^{210}$ See UnIf. R. Prac. SuP. CT. ARIZ., at XVII app. (Interrogatories 501-93).

211 See Neubauer, Check-the-Box Pleadings, Litigation, Winter 1985, at 28, 29, 54 (discussing California's form complaints).

212 See, e.g., Massachusetts Consumer Protection Act, Mass. ANN. Laws ch. 93A, $\S 9(6)$ (Law. Co-op. 1985) ("Any person entitled to bring an action under this section shall not be required to initiate, pursue or exhaust any remedy established . . . in order to bring an action under this section ...."); Gargan, Help for Buyers of 'Lemon' Cars Voted in Albany, N.Y. Times, June 14, 1983, at A1, col. 5 (New York law requires owners of "lemons" to resort to the manufacturer's arbitration process before suing for a refund or a new car); Landers, Of Legalized Blackmail and Legalized Theft: Consumer Class Actions and the Substance-Procedure Dilemma, $47 \mathrm{~S}$. CAL. L. REv. 842, 858-59 (1974) (discussing the tension between consumer protection statutes explicitly providing for class action remedies and the procedural rules regarding the requirements for bringing class action suits); McEttrick, The New Massachusetts Lemon Law, Mass. LAw. WeEKLy, Oct. 10, 1983, at 21 (reporting on Massachusetts' Lemon Law and provisions to channel cases arising under it into informal dispute settlement mechanisms).

${ }^{213}$ See Subrin, supra note 1, at 984. Also, the Manual for Complex Litigation applies to some "big" cases. See Manual For Complex Litigation (Second) $§ 10$ (1985) (purpose of manual is to set forth basic principles of complex litigation and describe procedures which have successfully implemented those principles).

214 See, e.g., Levy, Discovery-Use, and Abuse, Myth and Reality, 17 Forum 465, 468-69 (1981) (most discovery abuses are caused by a small number of giants involved in large and complex cases); $c f$. Lord, Discovery Abuse: Appointing Special Masters, 9 Hamline L. Rev. 63, 66 (1986) ("In larger and more complex cases it is not unusual that many months or even years are consumed by pettifoggery."). 
gators: small case and big case lawyers. ${ }^{215}$ In smaller cases there is less discovery and correspondingly less dissatisfaction with discovery abuse. ${ }^{216}$ Not surprisingly, in those cases that command a large fee, there is often little incentive for lawyer self-regulation. ${ }^{217}$

Authors have listed many reasons why over-discovery occurs: hourly pay, size of firms and their overhead, obsessive habits, computerization, fear of malpractice, the adversary system, the lawyer's obligation to the client, and judicial reluctance to sanction. It seems clear that in complex litigation or in litigation in which much is at stake, lawyers will frequently over-discover unless policed. ${ }^{218}$ Indeed, this understanding impelled the Federal Rule amendments of 1980 and 1983. 219

Courts have been reluctant, however, to manage litigation on an ad hoc basis; hence, the promulgation of time standards and of local rules that limit discovery. Some argue, though, that there are cases which need more lenient or different standards. ${ }^{220}$ Most attempts to limit discovery permit more discovery by discretion. But there is some indication that judges are reluctant to allow deviations. ${ }^{221}$ Moreover,

${ }^{215}$ Cf. Brazil, Civil Discovery: Lawyers' Views of Its Effectiveness, Its Principal Problems and Abuses, 1980 AM. B. Found. RES. J. 787, 790 (1980) [hereinafter Brazil, Civil Discovery] (arguing that big case litigation is more often infected by abuse of the discovery system than in smaller, less complex litigation); Brazil, Views from the Front Lines: Observations by Chicago Lawyers About the System of Civil Discovery, 1980 AM. B. Found. Res. J. 217-22 (1980) [hereinafter Brazil, Views] ("The world of civil discovery contains at least two clearly identifiable, major subworlds [small cases and large cases] between which there are significant differences.").

${ }^{216}$ See Brazil, Civil Discovery, supra note 215, at 799-809; Brazil, Views, supra note 215 , at $223,232-33$.

${ }^{217}$ Cf. Sherman \& Kinnard, supra note 100 , at 277 ("Market economics places a dominant value on maximization of individual preferences, and optimal economic efficiency may, in a particular case, sanction quite wasteful uses (in the layman's sense) of litigation resources.").

218 See, e.g., Brazil, Civil Discovery, supra note 215, at 865 ("The vast majority of big case lawyers believe that the bar simply can not exercise effective control over discovery in large lawsuits and that only aggressive judicial intervention can curb the excesses."); Levy, supra note 214, at 472 ("If the parties can abuse the discovery system with impunity, it is likely that the abuses will continue."); Renfrew, supra note 99, at 271 ("The growing awareness of the magnitude of the problem of abuse also should lower judicial barriers to the imposition of sanctions.").

${ }_{219}$ See, e.g., FED. R. GIV. P. 26(b) advisory committee note (1983 amendments) ("The rule contemplates greater judicial involvement in the discovery process and thus acknowledges the reality that it cannot always operate on a self-regulating basis.").

${ }^{220}$ See, e.g., Lundquist \& Flegal, Discovery Abuse-Some New Views About an Old Problem, 2 Rev. Litigation 1, 7 (1981) ("By differentiating the [discovery] rules, extensive discovery can be allowed when necessary without authorizing overuse of discovery in all types of cases."); Note, supra note 189, at 106 ("II]t may be impractical to establish a single limit [for interrogatories] to cover all cases." (footnote omitted)).

${ }^{221}$ See Sherman \& Kinnard, supra note 100 , at 265 \& n.82. 
some lawyers believe that some judges are biased against certain types of cases, which bias is shown in discovery motion decisions. ${ }^{222}$ As Administrative Law Judge Isaac Benkin noted, the question concerning the amount of discovery that should be afforded is not politically neutral. He found that those who favored government regulation also favored greater discovery; opponents of regulation tended to prefer restrictive discovery. ${ }^{223}$

Indeed, many authors have suggested that some procedural rules (including discovery rules) may have to be tailored to categories of cases. ${ }^{224}$ Courts are driven both to more precise limitations on discov-

222 See Brazil, Views, supra note 215, at 246 (citing civil rights actions as an example). Such bias may also reveal itself in cases involving other rules. See, e.g., Burbank, The Transformation of American Civil Procedure: The Example of Rule 11, 137 U. PA. L. REv. 1925, 1938 (1989) (over one year period in the Third Circuit, civil rights plaintiffs "were sanctioned at a rate $(47.1 \%)$ far higher than the rate for plaintiffs as a whole $(15.9 \%)$, and higher still than the rate for plaintiffs in non-civil rights cases (8.45\%)" (footnote omitted)); Carter, The Federal Rules of Civil Procedure As A Vindicator of Civil Rights, 137 U. PA. L. REv. 2179, 2182 (1989) (noting the "substantive bias' in the contemporary application of procedural rules" against plaintiffs asserting civil rights claims).

${ }^{223}$ See Benkin, The Inconstant Lady: Discovery in Administrative Adjudications and the Evidentiary Use of its Fruits, 4 ENERGY L.J. 201, 201-02 (1983).

224 See, e.g., Burbank, Of Rules and Discretion: The Supreme Court, Federal Rules and Common Law, 63 Notre Dame L. Rev. 693, 716-17 (1988) (posing questions why there should not be special rules applicable to RICO, civil rights, and complex cases generally); Cover, supra note 13, at 732 ("It is by no means intuitively apparent that the procedural needs of a complex antitrust action, a simple automobile negligence case, a hard-fought school integration suit, and an environmental class action ... are sufficiently identical to be usefully encompassed in a single set of rules . . . ."); Lundquist \& Flegal, supra note 220 , at 7 ("[D]iscovery rules should be revised to fit the particular nature of litigation in specialized areas. Discovery rules in antitrust cases inherently need to be different than rules for less complex civil litigation."); Rosenberg, The Federal Civil Rules After Half a Century, $36 \mathrm{ME}$. L. REv. $243,243-44$ (1984) (the use of "a monolithic set of rules applied to virtually all the varied types of civil actions filed in the federal district courts" compounds the problems that interfere with goals of speedy and inexpensive dispute resolution); Sander, Varieties of Dispute Processing, in The Pound Conference: Perspectives on Justice IN THE FUTURE 65, 84 (A. Levin \& $\mathrm{R}$. Wheeler eds. 1979), and reprinted in 70 F.R.D. 111, 131 (1976) (speculating on a Dispute Resolution Center of the future where a screening clerk would direct the litigant to the process most appropriate for her case); Subrin, supra note 1, at 991 ("There exist substantially different types of cases that may warrant different processes."). The idea of separate tracks for different types of cases is by no means new. In 1967, Benjamin Kaplan, Reporter to the Advisory Committee on Civil Rules, suggested that as part of a research project there be:

an attempt to classify the various types of court-litigated matters by their intrinsic qualities and functions with a view to deciding whether the unitary court procedures now in vogue could be deliberately altered to accommodate better to the several types. The general advantages of a unitary or common procedure are evident, but they may be overborne by other considerations in certain classes of cases.

Letter from Benjamin Kaplan to Dean Acheson, Esq. (March 2, 1967). This letter is reprinted within this issue as an appendix to Burbank, supra note 222, at 1964. 
ery, and to non-trans-substantive procedural rules. The general, flexible Federal Rules permitted lawyers to take advantage of the system, particularly in the large case. Therefore, attorney latitude gave way to flexible case-by-case management. Neither judges nor lawyers wanted every decision to be ad hoc. This concern led to absolute standards, with exceptions for good cause. But absolute standards may prejudice different cases. ${ }^{225}$ Such thinking leads to non-trans-substantive rules.

\section{Lessons FROM UNIFORMITy AND Divergence}

Nine years ago, shortly after I first started investigating the historical background of the Federal Rules, I wrote in an op-ed piece that "[a]pplying the rules to all cases, big and small, has proved disastrous. . . . We need a less-expensive process. Otherwise, ordinary disputes will continue to blossom into federal cases." ${ }^{226}$ Seven years ago I concluded a short article on the proposed Rule amendments with questions:

[I]t is critical to ask what cases and clients will be thwarted or aided by our deceptively neutral procedural choices. Will new signature requirements and discovery limits chill creative legal theories and legitimate litigation? Will emphasis on pre-commencement factual and legal investigation prejudice citizens who have fewer resources?

The debate over the 1981 proposals should be extended to include basic policy questions, for our procedural choices will necessarily be as value laden as those of our predecessors. $^{227}$

Senator Walsh and Connor Hall made sense to me when I first read them; they still do, although now I have also found George Dike of Boston. ${ }^{228}$ Acutely aware of my own predilections, I offer some lessons from the fifty years of uniformity and divergence under the Federal Rules.

${ }^{225}$ See supra notes $220-23$ and accompanying text. The more the Rules become biting, the more the need to protect specific types of cases from the bite. The losing battle to amend Rule 68 was instructive. It became clear that certain types of cases and litigants would be disproportionately adversely prejudiced by the proposed amendment. A trans-substantive rule would not work fairly. See Burbank, Proposals to Amend Rule 68-Time to Abandon Ship, 19 U. Mich. J.L. Ref. 425, 438 (1986).

${ }_{226}$ Subrin, The Law And The Rules, N.Y. Times, Nov. 10, 1979, at A23, col. 4.

227 Subrin, supra note 122 , at 1651 .

${ }^{228}$ See supra notes 177-84 and accompanying text. For other critics of the Federal Rules, see Subrin, supra note 1, at 992-1000. 


\section{A. Interdistrict Court Uniformity}

Senator Walsh and Connor Hall were correct: uniform federal rules have not led to as much procedural uniformity among the districts as Enabling Act supporters suggested. The country is too large and the judges, local rules, and legal cultures too diverse to permit the advertised uniformity. It is unlikely that a lawyer familiar with the procedure in one federal district court will feel equally comfortable with the procedure in another. ${ }^{229}$

\section{B. Federal District Court Judge Independence}

It is difficult to force a federal judge, or a group of them, not to have a local rule, standing order, or standing operating procedure if he, she, or they want one. Different judges will have different views about how to run their courts. Connor Hall emphasized the independence of the federal bench, and experience under the Conformity Act and the Enabling Act are consonant with such independence. A telling exchange between Thomas Shelton and Henry Taft, William Howard Taft's brother, at 1922 Senate Subcommittee hearings reinforces the independence lesson:

"Mr. Shelton: Federal practice is not anything like the State practice at all; . . . is there any way in the world in which you can make the courts conform to the State practice?

Mr. Taft: I did not think there was any way short of impeachment."230

\section{G. Intrastate Uniformity}

Walsh and Hall also accurately predicted that many states would stick to their procedural guns. By 1897, the Field Code system had been adopted in twenty-seven states, including such populous states as New York, California, and Ohio. As of 1890, 38,000,000 Americans out of $63,000,000$ ( $60 \%$ of the population) lived in Field Code states. Those data reflect considerably greater modeling than has occurred under the Federal Rules. ${ }^{231}$

229 See supra text accompanying notes 30-31 \& 98-112; cf. 1920 Rep. Comm. Unif. Jud. Pro., supra note 17, at 514 ("One objection [to uniform procedural rules] was to any change in the federal or state practice at all because some lawyers might be inconvenienced in having to learn a new system." (emphasis deleted)).

${ }_{230} 1922$ Senate Hearings, supra note 43, at 11. But see supra notes 113-14 and accompanying text (for developments that may substantially reduce the number of local rules; yet hundreds, if not thousands, will still remain).

${ }^{231}$ For the states adopting the Field Code, see C. Hepburn, The Historical 
Nonetheless, the Federal Rules have greatly influenced state procedure, and they have certainly dominated scholarly thought and the teaching of civil procedure in law school. But this does not mean, as promised, that a lawyer who knows the procedure in state court will thereby know the procedure in a federal court of the same state. ${ }^{232}$

\section{Reciprocal State-Federal Influence}

There is a continued cross-pollination between state and federal procedure, and across state lines as well. ${ }^{233}$ Future reciprocal influence may be quite subtle, however. If the federal courts see their primary function as resolving complex disputes, they may tailor their procedures to fit that image; ${ }^{234}$ if the state courts are more concerned with routine cases, they may emphasize limiting, definitional procedural rules or summary processes with few procedural steps. ${ }^{235}$

On the other hand, political considerations may compel the opposite agenda. If, as during the progressive era, the states become the laboratories for social experimentation, one may see much equity-like procedure in state courts; conversely, one may see in federal courts the use of formalism to obstruct rather than vindicate rights. ${ }^{236}$

\section{E. General Rules Leading to Specific Ones}

One can reduce the number of procedural rules and label them "uniform" and "simple," but judges will continue to exercise broad discretion (thus making the procedure uniform in name but not application) or will issue rules to limit discretion and standardize the practice.

Development of Code Pleading in America and England 14-15 (1897). The population figures are from H. Field, The Life of David Dudley Field 356 (1898) (letter from Thomas G. Shearman to David Dudley Field's brother, Dr. Henry Field, author).

${ }_{232}$ See supra text accompanying notes 98-135, 198-202.

${ }^{233}$ See supra text accompanying notes $166-76$ (discussing the case of Massachusetts) \& 192-93 (limits on interrogatories); see also Statement of Duties for Reporter to an Advisory Committee on Rules of Practice and Procedure, attachment to letter to the Chairmen and Reporters of the Judicial Conference Advisory Committees on Rules of Practice and Procedure (July 28, 1988) ("Examines the state experience in judicial procedure, giving particular attention to changes which have been made by those states which have followed the federal rules in adapting their local needs.").

${ }^{234}$ The 1980 and 1983 amendments to the Federal Rules already point in that direction.

${ }^{235}$ Cf. supra text accompanying notes 204-13 (tracking systems). Moreover, rules for the exceptional case at the state level may be borrowed from rules for the more normal complex case at the federal level.

${ }^{236}$ For the use of equity-like procedures to create new rights, see Subrin, supra note 1, at 912-13 (discussing scholarship of Professors Chayes and Fiss). On the use of formalism to defeat rights, see infra text accompanying notes 262-63. 
Legal training instills in a lawyer a general affinity for rules which may not be diminished upon a lawyer's elevation to the bench.

Again, procedural history is repetitive. David Dudley Field complained that his simple code of fewer than 400 provisions was brutalized by the New York legislature's massive accretions. ${ }^{237}$ In fact, when one adds to the original Field Code, as amended in 1849, those statutes incorporated by reference or not repealed, and those relating to the Justice and Surrogate courts, there were 2,473 sections to cover approximately the same topics that were covered in 1919 by the 2,732 sections of the Throop Code, as amended. ${ }^{238}$ Local rule proliferation may represent the same phenomenon.

Once again, Walsh and Hall were right. One can have an equitylike procedural system, such as the Federal Rules, which looks simple. As they warned, however, equity required centuries to develop, many treatises to explicate, and a specialized bar. ${ }^{239}$ The procedural system spawned by the Enabling Act could not ultimately be as simple and problem-free as the proponents claimed.

\section{F. Legal Culture}

One reason that it is difficult for procedural reform to achieve its stated goals is that procedural rules do not work in a vacuum. Walsh and Hall warned that one must consider how the procedural rules will mesh with the legal culture within which they must operate. ${ }^{240}$ The habits and customs of the bench and bar, the procedural rules, and the economic, social, and political agendas of the lawyers, clients, judges, and other court personnel interact with one another. ${ }^{241}$

${ }^{237}$ See Letter from David D. Field to Cephas Brainerd, Rowland M. Hall, P. Van Alstine \& James A. Ross, in The LAtest Edition of The New York Code of Civil Procedure, Correspondence Between Cephas Brainerd and Others and David Dudley Field 3, 11-12, 15 (1878).

${ }^{238}$ See Report of the Joint Legislative Committee on the SimplificaTION OF Grvil. Procedure 9-12 (1919).

${ }^{239}$ See supra text accompanying notes 51 \& 59.

${ }^{240}$ See supra text accompanying notes $54 \& 58$.

241 On how civil procedure has broader socio-economic and professional dimensions, see Subrin, supra note 1, at 966; Subrin, supra note 15, at 311 . On the interconnected nature of the human enterprise, see Edmund Wilson's description of the maturation of Jules Michelet as a historian. Wilson quotes Michelet: "Woe be to him who tries to isolate one department of knowledge from the rest. . . All science is one: language, literature and history, physics, mathematics and philosophy; subjects which seem the most remote from one another are in reality connected, or rather they all form a single system." "E. Wilson, To the Finland Station, A StUdy in the WRITING AND ACTING OF History 5-6 (1940) (omission in original). 


\section{G. Uniformity of Result and the Third Procedural Spirit}

The uniform federal rules movement started with notions of interdistrict court and intrastate uniformity, and ended up embracing trans-substantive uniformity. ${ }^{242}$ Federal and state judges voted for local rules and issued standing orders, and some commentators now applaud the local divergence. They argue that local rules permit adjustment to local conditions, facilitate experimentation, and create efficiencies. ${ }^{243}$ Some argue that the bar benefits when lawyers know where a judge stands. ${ }^{244}$

But the current proponents of local rule divergence, like the proponents of the Federal Rules fifty years ago, tend to undervalue the most important type of uniformity-uniformity of result. As Hall argued, a major purpose of procedure is to help substantive law be applied in a constant fashion. ${ }^{245}$ Perhaps the primary goal of uniform rules in non-test case litigation should be to help similar cases end up with similar results in an efficient and economic manner. ${ }^{246}$

Although Shelton and Clark argued, on occasion, that procedural law is merely "adjective," a "handmaiden" to justice, ${ }^{247}$ some Federal Rules and some local rules considerably influence the results of litigation or the settlement value of cases. When discovery is tightly regulated by local rule in one federal district court but not in another, are the litigation results really the same?248 If discovery is as important as most lawyers believe it is, and if judges are as human as we know they are, can there be equal justice under law? Can similar cases be decided in similar ways and with similar results when the discovery rules and other rules have become so divergent?

Procedural rules, as flexible and as judge-empowering as the Federal Rules, have always implied non-uniformity of treatment, with or

${ }^{242}$ See supra text accompanying notes 39-40.

${ }^{243}$ See supra note 90 and accompanying text.

244 See Flanders, Local Rules, supra note 95, at 268; cf. Flanders, In Praise, supra note 95 , at 35 (noting that the most common complaint the author hears from lawyers is the difficulty in practicing law where procedures differ widely from judge to judge).

245 See supra text accompanying note 62.

24 See Subrin, supra note 1 , at $982-91$.

247 See id. at 962.

${ }^{248}$ The advisory committee evidently thought it was important that poorer clients could afford interrogatories, but not depositions, when they rejected interrogatory limitations. See Amendments to the Federal Rules of Civil Procedure, 85 F.R.D. 521, 54344 (1980); supra note 127. In the districts that require a motion for additional interrogatories beyond the limit, clients, some of them poor, will have to pay for the motion. Some of the motions will be lost and some cases will be lost because of a dearth of discovery or affordable discovery. Federal judges, like all human beings, are different and have predilections and biases. 
without local rules. Recognizing this fact, we should welcome more formalized procedural rules. Moreover, this recognition is one reason for the evolution of the third procedural spirit: an attempt to achieve the uniformity of application that neither the original Federal Rules nor ad hoc case management could readily deliver. ${ }^{249}$

\section{H. The Fourth Procedural Spirit: Non-trans-substantive Procedure and Political Considerations}

The third procedural spirit invites the fourth: different rules for different cases, or non-trans-substantive civil procedure. When one begins to define procedures more rigorously, it becomes obvious that some cases need different rules. ${ }^{250}$ Some scholars have suggested problems with this development. ${ }^{251}$ Before addressing their concerns, two words of caution are in order.

First, it is not a question of wanting or not wanting non-transsubstantive procedure. As the exploration of local rule and state variations has suggested, non-trans-substantive procedure is already here; some cases already have special pre-determined procedural rules. ${ }^{262}$ Even under the Federal Rules as now written and administered, caseby-case management may often result in procedure being tailored to particular cases; in such management, judges may often apply pre-defined procedures to pre-determined categories of cases. ${ }^{253}$

Second, no one, to my knowledge, has suggested a return to a writ

249 There were arguments by the Legal Realists about how formalism can lead to a lack of uniformity, and how flexible, discretionary rules can help achieve uniformity of result. I think the arguments are flawed. See Subrin, supra note 15, at 342-43.

250 See supra notes 220-25 and accompanying text.

201 See A.L.I., Study on "Paths to a 'Better Way': Litigation, Alternatives, and Accommodation," Background Paper 97-100 (July, 1988); Carrington, Making Rules to Dispose of Manifestly Unfounded Assertions: An Exorcism of the Bogy of NonTrans-Substantive Rules of Civil Procedure, 137 U. PA. L. Rev. 2067, 2068 (1989); Hazard, Discovery Vices and Trans-Substantive Virtues in the Federal Rules of Civil Procedure, 137 U. PA. L. REv. 2237, 2244-46 (1989); Sarat, The "New Formalism" in Disputing and Dispute Processing (Book Review), 21 LAw \& Soc'y REv. 695, 698, 705-712 (1988) (reviewing Dispute Resolution (S. Goldberg, E. Green \& F. Sander eds. 1985)). I believe that Professor Sarat underestimates the potential of formalized rules (non-trans-substantive or otherwise) to help vindicate rights. One can understand the political nature of procedure, and seek distributive justice, and also see the value of definitional legal doctrine. See Subrin, supra note 15, at 338-45:

252 See supra text accompanying notes $220-25$.

${ }^{203}$ Some judges have told me that they have different pre-written orders available for different types of cases. See also FED. R. CIV. P. 16(b) advisory committee note (1983 amendments) ("The district courts undoubtedly will develop several prototype scheduling orders for different types of cases."). "Non-trans-substantive" may be a misleading phrase. As suggested in the text of the next paragraph, it may make sense to type some cases by substantive law, and others by complexity, the stakes, or the nature of the litigants or their lawyers. 
system where every cause of action will have a multiplicity of unique procedural characteristics. ${ }^{254}$ For the foreseeable future, general procedural rules applicable to all cases will be the backdrop for most formal litigation. There are many questions in this developing new procedural era: i) what types of cases need some different procedures; ii) can the case types be determined in advance; iii) should the case be typed by the substantive law involved, the degree of complexity, the stakes involved, the nature of the litigants or their lawyers, or might these and other indicia all be used; iv) what should the procedural differences be, bearing in mind that the general procedural rules will cover most procedural steps unless and until modified; and v) who should make the decisions: legislators, the judiciary, the individual judge, or the litigants?285

The first major criticism of the emerging pattern of non-trans-substantive procedure is that the transaction costs are too high: lawyers will argue about which category is appropriate, judges will have to make decisions, and clients will pay for the procedural arguments. ${ }^{256}$ This misses the point. Gase-by-case management developed because the transaction costs of procedural rules with broad attorney latitude were too high. As a result of federal local rules and state experimentation, the judiciary has already demonstrated that it thinks the transaction costs of ad hoc case-by-case management are also too high. Judges are already turning to formal limitations and definitions in order to reduce transaction costs. This third spirit inevitably leads to the fourth spirit, non-trans-substantive procedure. The same limitations or formalized requirements do not make sense for all cases. One could try to solve this problem by making the new, more definitional rules, such as those

254 See A.L.I., supra note 251, at 88. The description of the common law forms and their accompanying procedure may itself be a caricature. Many attributes of common law pleading and practice were common from writ to writ. See S. Milsom, HisTORICAL Foundations of the CoMmon Law 38-39, 67-70, 72-73 (2d ed. 1981); C. Rembar, The LAw of THE LAND 224-28 (1980). But, of course, the writs often did imply procedures individualized to the specific writ. See F. MAITLAND, EqurTY, Also THE Forums of Action at Common Law 295-300 (1920).

${ }_{255}$ The criteria to be used for applying some procedures to selected cases may prove difficult to define, and, as to some procedures, there may be no clear-cut criteria. For example, a study of "Early Neutral Evaluation" (ENE) of cases in the Northern District of California suggests that "there emerges no pattern from the data collected that would clearly suggest that there are characteristics of either the cases, the attorneys, or the parties that a court could use in a consistent and fairly ministerial manner to decide whether to refer cases to ENE. If the views of the participants are a reliable guide, ENE appears to be equally well-received along any of these dimensions." Levine, Early Neutral Evaluation: The Second Phase (forthcoming, $1989 \mathrm{~J}$. DisPuTe RESOlution). A short version is printed in 70 Judicature 236-40 (1987).

${ }^{288}$ See A.L.I., supra note 251, at 99-100; Carrington, supra note 251, at 2088- 
that curtail discovery, subject to motions for exceptions on a case-bycase basis. But this entails increased transaction costs, decreased predictability, and increased possibility of bias against classes of cases or litigants. ${ }^{257}$

Second, there is a fear that different rules for different cases will render procedure too political. The current reporter to the advisory committee, Paul Carrington, stresses the importance of procedural neutrality (not favoring or disfavoring types of cases or litigants), and suggests that the "have-nots" will be even worse off if procedural rulemaking is subject to political lobbying. ${ }^{258}$ But procedural discourse and reform in this country have always had a substantial political dimension. I have documented elsewhere the political underpinnings of both the Field Code and Federal Rules reform. ${ }^{259}$

The political dimension is not limited to major procedural reform movements; many individual procedural rules or clusters of rules have an inherently political aspect, in that they favor or disfavor types of cases or litigants. ${ }^{260}$ For instance, flexible, broad, trans-substantive rules, such as the Federal Rules, particularly prior to the amendments of the 1980s, permitted (if not invited) the growth of rights for minorities, consumers, and the environment. ${ }^{261}$ In Title VII employment discrimination cases, both the substantive and procedural law have already been interpreted or altered by the courts in an integrated writ-like manner, to the detriment of the rights of the people who were supposed to be protected by the statute. ${ }^{262}$ Non-trans-substantive procedure ap-

257 See supra text accompanying notes 220-23. Tracking systems can, and do, permit motions to place the case on a different track. See supra text accompanying note 207. This will entail some transaction costs, but not so much as arguing about and making ad hoc decisions in each case. On what may be the costs of case-by-case management, see Kritzer, Grossman, McNichol, Trubek \& Sarat, Courts and Litigation Investment: Why Do Lawyers Spend More Time on Federal Cases?, 9 JusT. Sys. J. 7, 15-16 (1984) (also pointing out the potential difference in legal culture between state and federal courts). On the dearth of evidence on cost or time savings from case management, see Resnik, Managerial Judges and Court Delay: The Unproven Assumptions, JUDGES' J., Winter 1984, at 8, 10.

${ }_{258}$ See Carrington, supra note 251, at 2085-86.

${ }_{259}$ See Subrin, supra note 1, at 909-1002; Subrin, supra note 15, at 309-45.

260 See Burbank, supra note 222, at 1938; Carter, supra note 222, at 2183-84; Hazard, supra note 251 , at 2246-48.

${ }^{281}$ See Carter, supra note 222, at 2179-80; Chayes, The Role of the Judge in Public Law Litigation, 89 HARv. L. Rev. 1281, 1292-96 (1976); Fiss, Foreward: The Forms of Justice, 93 HARv. L. Rev. 1, 2, 5 (1979); Fiss, The Social and Political Foundations of Adjudication, 6 LAw \& Hum. BeHAv. 121, 121-22 (1982); Hazard, supra note 251, at 2246; Oakes, "A Plague of Lawyers?": Law and the Public Interest, 2 VT. L. REV. 1, 2, 11-16 (1977); Weinstein, supra note 164, at 1912.

${ }^{262}$ Professors Judith Olans Brown, Phyllis Tropper Baumann, and I are working on a paper documenting the various areas in which the federal courts, and particularly the Supreme Court, have interpreted and altered the law to the detriment of those who 
pears in this instance to have already developed, but regretfully to defeat rather than vindicate congressionally created rights.

If legislators want the rights proclaimed in statutes translated into real gains for citizens they will have to consider some procedural incidents when they enact laws. ${ }^{263}$ Walsh was at least part right; some procedural rules will require legislative hearings and legislative votes. $^{264}$

\section{Creative Lawyers and Manipulating Procedural Systems}

History teaches that any American procedural model will be modified by the ingenuity of lawyers who have learned to manipulate the rules to the benefit of their clients. ${ }^{265}$ Non-trans-substantive procedure cannot avoid a similar fate. Fifty years from now critics will surely complain that some of us who could see the flaws of generality, flexibility, and discretion were blind to the inefficiencies and injustices of linedrawing. We will just as surely be accused of undervaluing equity in the fruitless search for certainty. ${ }^{268}$

\section{CONCLUSION}

The quest to have just laws consistently and expeditiously applied, while at the same time allowing the exceptional claim or defense of merit and pursuing the evolution to more humane law, is not an easy one. Nor are the goals fully obtainable. But why should we spend our professional lives studying, teaching, drafting, and applying procedural law, or celebrate the fiftieth anniversary of a bunch of procedural rules, for a less lofty vision? Some tedious journeys are worth incompleteness.

were given rights by Title VII. Areas we are studying include: definition of prima facie case and affirmative defenses; burdens of proof; statutes of limitations; discovery; intervention; class actions; Rule 11; attorney fees; standard of review; res judicata and collateral estoppel. The paper will demonstrate some of the ways in which the substantive law and procedures have been integrated.

${ }_{263}^{26 e}$ Se, e.g., supra notes $210-13$ and accompanying text (giving examples of procedural rules tailored to specific categories of cases).

${ }_{264}^{26}$ See supra text accompanying note 55.

${ }^{265}$ Specialized pleading at common law, trying to determine what was a "fact" or the "theory of the case" under the Field Code, and liberal discovery under the Federal Rules each have provided fertile ground for creative lawyers with clients who could afford to pay for legal victories that they thought were worth the price.

${ }^{266}$ We will not even have to wait that long. See, e.g., Carrington, supra note 251, at 2070 (advocating a greater emphasis on equity in the formation of procedural rules); Hazard, supra note 251, at 2247 (same); Shapiro, supra note 10, at 1977 (same); Weinstein, supra note 164, at 1923-24 (same). 
